\title{
TOP-DOWN OR SHARED LEADERSHIP? EXAMINING DIFFERENCES IN ATHLETE LEADERSHIP BEHAVIOURS BASED ON LEADERSHIP STATUS IN SPORT
}

\author{
Alyson J Crozier ${ }^{1}$, Todd M Loughead ${ }^{2}$, Krista J Munroe-Chandler ${ }^{2}$ \\ ${ }^{1}$ University of South Australia, School of Health Science, Adelaide, South Australia, Australia \\ ${ }^{2}$ University of Windsor, Department of Human Kinetics, Windsor, Ontario, Canada
}

\begin{abstract}
The purpose of this study was to examine differences in athlete leadership behaviours based on one's athlete leader status. Intercollegiate athletes $(\mathrm{N}=299)$ self-identified their leadership status (i.e., formal leader, informal leader, follower) and rated the frequency of their own leadership behaviours. Results revealed that formal athlete leaders engaged in Training and Instruction more often than informal athlete leaders; with informal athlete leaders reporting higher frequencies than followers. Further, formal and informal athlete leaders reported engaging in Social Support more often than followers. These findings provide preliminary evidence of a top-down approach to leadership among athletes. No differences were found for Democratic Behaviour and Positive Feedback, suggesting that athlete leadership also is distributed among teammates. Results highlight important practical implications for sport practitioners in regard to athlete leader development.
\end{abstract}

Keywords: SHARED LEADERSHIP /GROUP DYNAMICS/SPORTS TEAMS/STATUS/ ATHLETE LEADER

\section{INTRODUCE}

There is an emerging consensus in the sport literature that athlete leadership is important for both individual and team outcomes. Specifically, the behaviour of athlete leaders positively contribute to player satisfaction/enjoyment (Eys, Loughead, \& Hardy, 2007; Price \& Weiss, 2013), confidence (Fransen, Coffee, et al., 2014; Price \& Weiss, 2013), team cohesion (Callow, Smith, Hardy, Arthur, \& Hardy, 2009; Vincer \& Loughead, 2010), and performance (Callow et al., 2009). Given these positive benefits, it would appear worthwhile to examine factors which may impact the behaviour athlete leaders display. One such factor may be an athlete's leadership status on the team, as researchers have identified multiple athlete leadership roles which exist in sport (Cro- zier, Loughead, \& Munroe-Chandler, 2013; Fransen, Coffee, et al., 2014; Loughead, Hardy, \& Eys, 2006).

In particular, status reflects the amount of importance or prestige an individual possesses or is accorded by virtue of their position in relation to others (Jacob \& Carron, 1998). As such, individuals within a group setting can be categorized hierarchically according to their perceived status in comparison to others. In other words, those who have greater status would be positioned higher on the status hierarchy than someone with lower status. In sport, four major sources of status (Jacob Johnson, 2004) have been identified, which include an individual's physical attributes (e.g., performance, experience, role as leader, playing position), psychological attributes (e.g., positive attitude, fostering team spirit), demographic attributes (e.g., age, in- 
come), and relationships with external others (e.g., parental support). Although it can be argued that all four sources of status are important for sport teams, the present study focused on the physical attribute of an athlete's role on the team, and in particular the role of being an athlete leader. In fact, the role as leader is one of the most important sources of status endorsed by team sport athletes (Jacob \& Carron, 1998).

In their study, Jacob and Carron (1998) used captains or co-captains to define the role as leader. This frame of reference is of particular interest given that being an athlete leader can be more than simply being prescribed a leadership role such as being named as team captain. Rather, athlete leadership is a complex, dynamic process in which the leadership roles within teams is assumed by multiple athletes (Bucci, Bloom, Loughead, \& Caron, 2012; Crozier et al., 2013; Fransen, Vanbeselaere, De Cuyper, Vande Broek, \& Boen, 2014). The notion that leadership roles can be occupied by numerous individuals is rooted within the approach of leadership being shared or distributed (Pearce \& Conger, 2003). The concept of shared leadership is in contrast to the traditional approach where one person is in charge with others following. This traditional top-down approach has dominated the research of leadership within sport which has examined the role of the coach as leader. Only in the past decade has research been paid to understanding shared leadership in sport, such that both coaches and athletes can provide leadership within the team (Loughead \& Hardy, 2005).

In regard to athlete leadership specifically, the role of athlete leader is defined as an athlete occupying a formal or informal role within a team who influences other team members toward achieving a common goal (Loughead et al., 2006). This definition highlights that leadership roles can be shared or broadly distributed among members of the team, and that two types of athlete leader roles exist. Formal leaders are those individuals designated as leaders by the organization or team (e.g., captains), whereas informal leaders are those individuals who emerge as leaders through experience and interactions with other team members. Since this definition of athlete leader was proposed, a third role which has been acknowledged by researchers is the role of the athlete non-leader (i.e., the follower) (Crozier et al., 2013).

The present study was guided by Locke's (2003) integrated model of leadership developed in organizational psychology, which proposes that shared leadership involves both upward or downward hierarchical influence and lateral influence. When applied to athlete leadership, the hierarchical influence would indicate that captains and assistant captains (formal types of leaders) are recognized as the highest source of athlete leadership status, followed by informal athlete leaders, and then by followers (i.e., hierarchical influence). As for the lateral influence of the model, team members are viewed as being equal and interdependent with each other (regardless of status). Several assumptions are associated with Locke's model. The first is that all team members are not created equally based on their status - formal leaders have greater status than informal leaders, and both types of athlete leaders having greater status than followers. The second assumption is that both lateral and hierarchical influence contributes to team effectiveness and should not be considered mutually exclusive (Pearce \& Sims, 2002).

While Locke's (2003) integrated model of leadership has not been examined, to our knowledge, in relation to athlete leadership, research has indicated that a formal hierarchy does exist in sport, which provides structure regarding how individuals should enact their roles (Benson, Hardy, \& Eys, 2016). Further, there is some evidence highlighting the models applicability, in that certain athlete leadership roles (i.e., formal and informal) may provide differing and/or similar types of leadership behaviours to their team. In a qualitative examination of the benefits associated with the presence of formal and informal athlete leaders, Crozier et al. (2013) reported that task leadership behaviours were cited as a benefit associated with formal leaders (e.g., captains) but not for informal leaders. In contrast, the results further identified the leadership behaviours of encouraging teammates and seeking input from teammates as important behaviours of both formal and informal leaders. While these findings 
suggest that formal and informal leaders are beneficial in that they provide different but also similar leadership behaviours to their team, it was not able to assess the relative frequency of behaviour that the different leadership roles exhibit.

Further, with some exceptions (e.g., Benson, Hardy, \& Eys, 2016) there has been little research to date examining the role of followers in sport. From organizational psychology we know that followers are associated with having less responsibilities than leaders (Vanderslice, 1988) and that they are viewed and feel less important than those who occupy leadership roles (Hoption, Christie, \& Barling, 2012). However, what the above results fail to indicate is whether athletes (leaders and followers) engage in similar or different amounts of leadership behaviours contingent on their leadership role (status). Determining which behaviours athletes in different leadership roles perceive themselves to display would provide practical knowledge for professionals working with athletes (i.e., coaches, sport psychologists). In particular, knowing which athletes (i.e., roles) are displaying specific leadership behaviours would allow practitioners to develop leadership training programs tailored specifically for an entire sport team. Currently, much of the leadership training athletes receive is catered toward the formal leader (Gould \& Voelker, 2010). However, informal leaders also act as a primary source of leadership to many athletes (Fransen, Vanbeselaere, et al., 2014), and thus should be provided opportunities to enhance their leadership skills.

In terms of the leadership behaviours of interest to the current study, although a variety of measures have been used to assess athlete leadership, the Leadership Scale for Sports (LSS; Chelladurai \& Saleh, 1980) has shown strong psychometric properties compared to other measures modified to assess athlete leader behaviours (Loughead, 2017). In particular, the LSS measures five dimensions of leadership behaviour: Training and Instruction (improve athletic performance); Positive Feedback (recognize and reward good performance); Social Support (show a concern for the welfare of team members); Democratic Behaviour (allow team members to participate in decision-making); and Autocratic
Behaviour (make decisions independently of team members).

Therefore, the purpose of the current study was to examine whether there are differences between an individual's leadership behaviours within team sports depending on one's self-rated athlete leadership status. On the one hand, Locke's (2003) integrated model of leadership would suggest differences in leadership behaviours based on an individual's status (i.e., top-down approach). As research has indicated that formal leaders are cited more frequently than informal leaders as performing task-oriented functions (Fransen, Vanbeselaere, et al., 2014; Loughead et al., 2006), it was hypothesized that athlete leaders would differ in the frequency in which they reported engaging in Training and Instruction behaviours. Further, as captains have indicated they use autocratic techniques (as part of their role, see Dupuis, Bloom, \& Loughead, 2006), it was hypothesized that formal athlete leaders would engage in more Autocratic Behaviour compared to informal leaders. On the other hand, the model also suggests there is the possibility that leadership is shared and there would be no differences based on status (i.e., shared approach). Given that research has reported athlete leaders, regardless of formal/informal status, are beneficial as they provide support to teammates as well as seek input from teammates (Crozier et al., 2013), it was hypothesized that frequency of Social Support, Positive Feedback, and Democratic Behaviour would not differ based on athlete leader status, such that these behaviours are shared similarly among athlete leaders. Last, as there is evidence in organizational literature that followers view themselves as having less responsibilities (Vanderslice, 1988) and are less important than leaders (Hoption et al., 2012) it was predicted that followers may engage in leadership behaviours to a lesser extent than athlete leaders. However, as there is a paucity of research in sport examining followers, no a priori hypotheses were advanced for which specific leadership behaviours would differ from those of the athlete leaders. 


\section{METHODS}

\section{Participants}

A total of 299 intercollegiate athletes (90 male, 209 female) from both college and university intercollegiate teams participated in the study. All participants competed in either the Ontario University Athletics (OUA) Association or the Ontario Colleges Athletic Association (OCAA) and were members of interdependent sports teams that included basketball $(n=43)$, ice hockey $(n=122)$, and volleyball $(n=134)$. The mean age of the participants was 20.71 years $(S D=2.07)$. The participants had been involved with their current team for an average of 2.17 years $(S D=1.19)$.

\section{Measures}

Athlete leader status. Athlete leader status was determined by the participant self-identifying the leadership role they occupied on their current team. Participants were presented with a description of a formal athlete leader (i.e., an athlete that is selected by the team or coach to be in a leadership position, such as captain, co-captain or assistant captain) and an informal athlete leader (i.e., established through interactions with team members, not formally appointed by coach or team). The participants were asked to select one of these two athlete leadership roles as it applied to them. If a participant did not select either of these two options, they were classified as a follower. This method has been used in previous research in order to categorize athletes into the leadership role they perceived themselves as occupying (Crozier et al., 2013; Martin, Balderson, Hawkins, Wilson, \& Bruner, 2016). Although we acknowledge the discrete nature of this categorization, this method was deemed appropriate for classifying athletes into their self-rated leadership status for this study. Similar categorization methods have been used in research examining starting status (i.e., whether they are a player who begins the competition on the playing surface and typically receives regular playing time; Eys, Carron, Bray, \& Beauchamp, 2003) whereby self-rated starting status was a variable of interest (Jeffery-Tosoni, Eys, Schinke, \& Lewko, 2011). In this study, results indicated that 67 (22.4\%) participants identified themselves as a formal athlete leader, 135 (45.1\%) as an informal athlete leader, and 98 (32.5\%) were classified as an athlete non-leader. The leadership dispersion found in the current study using a self-selection method of leadership is similar to what research has found in previous studies (Crozier et al., 2013; Fransen, Coffee, et al., 2014; Fransen, Vanbeselaere, et al., 2014).

Athlete leader behaviours. The participants self-rated their own leadership behaviours using the Leadership Scale for Sports (LSS; Chelladurai \& Saleh, 1980). The LSS has typically been used to measure transactional coaching behaviours but has been used effectively to assess athlete leadership behaviours (Loughead \& Hardy, 2005; Vincer \& Loughead, 2010). In addition, the LSS has shown strong psychometric properties compared to other measures that have been modified when assessing athlete leader behaviours (Loughead, 2017). The LSS is a 40 -item inventory that measures five types of leadership behaviours. The Training and Instruction dimension consists of 13 items and assesses leadership behaviour aimed at improving athletic performance (e.g., "I explain to team members the techniques and tactics of the sport"). Positive Feedback contains five items and reflects the tendency to reinforce behaviour by recognizing and rewarding good performances (e.g., "I express appreciation when a team member performs well"). The dimension of Social Support consists of eight items and reflects the degree to which an individual shows concern for the welfare of his/her teammates (e.g., "I help team members with their personal problems"). The Democratic Behaviour dimension consists of nine items and reflects the extent an individual allows participation from teammates in decision-making (e.g., "I let fellow team members share in decision making"). Autocratic Behaviour includes five items and represents the tendency to make decisions independently from the team (e.g., "I work relatively independent of other team members"). All items were scored on a 5-point Likert type scale anchored by 1 (never) and 5 (always). The LSS has demonstrated convergent (Paradis \& Loughead, 2012) and discriminant (Vincer \& Loughead, 2010) validity, as well as acceptable internal reliability values when assessing 
athlete leadership behaviours in athletes (Loughead \& Hardy, 2005; Vincer \& Loughead, 2010). Thus, this inventory is measuring its targeted constructs making it a viable tool for measuring leadership behaviours in athletes. For the current study, it should also be noted that the athlete leadership dimension of Autocratic Behaviour had an alpha coefficient of .61 and was removed from further analyses.

\section{Procedure}

Following university ethical approval, coaches were contacted via e-mail seeking permission to survey their athletes. After each coach had given permission, a convenient time was set to meet with the athletes prior to or after a practice session. At this meeting, the purpose of the study was explained to the athletes. Confidentiality of individual responses was assured with the primary researcher administering the questionnaires (i.e., demographic details, athlete leader status, and LSS) in separate unmarked envelopes. Completed questionnaires were placed back into the envelope to further ensure confidentiality. The return of the questionnaires signified consent to participate in the study and completion of the questionnaires took approximately 15 minutes. In addition, all participants were given the opportunity to fill out a ballot for a chance to win a $\$ 50$ gift certificate to a sporting goods store as an incentive to participate in the study.

\section{Data Analysis}

In order to address the study's purpose, a MANOVA was conducted to examine if formal athlete leaders, informal athlete leaders, and athlete followers would differ in the frequency in which they displayed certain leadership behaviours. An athlete's self-rated leadership status served as the independent variable, with the four remaining dimensions of the LSS serving as dependent variables. As the distribution among leadership statuses were unequal, the Pillai's trace statistic was examined as it is considered the most robust statistic when data violates MANOVA assumptions (i.e., equal cell sizes; Olson, 1974).
If significant, to determine which specific athlete leadership behaviours differed in relation to athlete leader status, post-hoc analyses were conducted. Post-hoc univariate ANOVAs have typically been used to determine where the differences are found in a MANOVA (Huberty \& Morris, 1989; Tonidandel \& LeBreton, 2013), and are the dominant follow-up procedure in sport and exercise psychology research (e.g., Greenlees, Webb, Hall, \& Manley, 2007; Landers, Arent, \& Lutz, 2001; Loughead \& Hardy, 2005; Weiss \& Smith, 2002). However, there is one major shortcoming to using successive univariate ANOVAs to follow-up a significant MANOVA. By utilizing multiple ANOVAs, researchers are ignoring the correlations found between dependent variables (Bray \& Maxwell, 1982; Dillon \& Goldstein, 1984; Huberty \& Morris, 1989). In order to account for correlated dependent variables in a MANOVA design, Tonidandel and LeBreton (2013) have applied the technique of relative weight analysis (Johnson, 2000) to the post-hoc assessment of significant MANOVAs. Relative weight analysis uses a variable transformation approach that creates a set of new variables that is maximally related to the original variables but are orthogonal (uncorrelated) to one another. Thus, relative weight analysis allows researchers to evaluate the relationship between the independent variable (i.e., athlete leader status) and the dependent variables (i.e., athlete leadership behaviours) while taking into account the intercorrelations among the dependent variables. Thus, relative weight analysis (Tonidandel \& LeBreton, 2011) was conducted using the $\mathrm{R}$ statistical package ( $\mathrm{R}$ Core Team, 2013) to control for potential intercorrelations between the four athlete leadership behaviours. The relative weights associated with each dependent variable (i.e., athlete leadership behaviours) represented a measure of relative effect size (i.e., the percentage of variance accounted for in each dependent variable by the independent variable; Tonidandel \& LeBreton, 2013). Further, in order to account for family-wise error with four dependent variables, a Bonferroni adjustment was applied $(p=.05 / 4<$ .0125 ) to a Tukey post-hoc comparison with strict confidence intervals (99\% confidence interval [CI]). 


\section{RESULTS}

\section{Descriptive Statistics}

Table 1 contains the means, standard deviations, and alpha coefficients of the variables examined in the present study. In general, the means suggest that these athletes perceived themselves as providing medium to high frequencies of leadership behaviours (means ranged from 3.00 to 4.29, a 5-point scale). Table 2 contains the correlation coefficients between the four athlete leadership behaviours.

Table 1. Means and standard deviations for the leader behaviour dimensions distinguished by leadership status

\begin{tabular}{|c|c|c|c|c|}
\hline Variable & Formal & Informal & Non-Leader & $\alpha$ \\
\hline Training and Instruction ${ }^{\mathrm{a}}$ & $\begin{array}{l}3.61 \\
(.65)\end{array}$ & $\begin{array}{l}3.28 \\
(.63)\end{array}$ & $\begin{array}{l}3.00 \\
(.67)\end{array}$ & .90 \\
\hline Democratic Behaviour $^{\mathrm{a}}$ & $\begin{array}{l}3.76 \\
(.53)\end{array}$ & $\begin{array}{l}3.59 \\
(.57)\end{array}$ & $\begin{array}{l}3.53 \\
(.54)\end{array}$ & .70 \\
\hline Social Support ${ }^{\mathrm{a}}$ & $\begin{array}{l}4.13 \\
(.51)\end{array}$ & $\begin{array}{l}3.97 \\
(.59)\end{array}$ & $\begin{array}{l}3.72 \\
(.59)\end{array}$ & .79 \\
\hline Positive Feedback ${ }^{\mathrm{a}}$ & $\begin{array}{l}4.27 \\
(.57)\end{array}$ & $\begin{array}{l}4.29 \\
(.49)\end{array}$ & $\begin{array}{l}4.16 \\
(.53)\end{array}$ & .76 \\
\hline Autocratic Behaviour ${ }^{\mathrm{a}}$ & $\begin{array}{l}2.62 \\
(.67)\end{array}$ & $\begin{array}{l}2.62 \\
(.67)\end{array}$ & $\begin{array}{l}2.55 \\
(.66)\end{array}$ & $.61^{*}$ \\
\hline
\end{tabular}

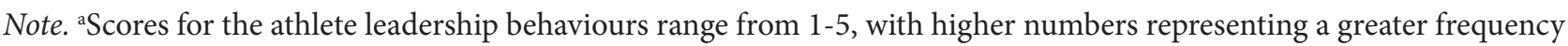
${ }^{*}$ Dimension was deleted from further analyses due to low alpha value; Standard deviations are contained within the parentheses underneath their respective means.

Table 2. Bivariate correlations between athlete leadership behaviour dimensions

\begin{tabular}{lccc}
\hline Variable & 2. & 3. & 4. \\
\hline 1. Training and Instruction & $.496^{* *}$ & $.452^{* *}$ & $.314^{* *}$ \\
2. Democratic Behaviour & - & $.423^{* *}$ & $.406^{* *}$ \\
3. Social Support & & $-406^{* *}$ \\
4. Positive Feedback & & - \\
\hline Note. ${ }^{* *} p<.01$ & &
\end{tabular}

\section{Main Findings}

The overall MANOVA revealed a significant multivariate effect for leadership status, Pillai's trace $=.138, F(8,588)=5.447, p<.001, \eta^{2}=.069$, indicating that an athlete's self-rated leadership status significantly differentiated the self-rated frequency of leadership behaviours. The results of the relative weight analysis are presented in Table 3, and show that the independent variable of athlete leader status was significantly different for the athlete leadership behaviours of Training and Instruction (e.g., providing instruction to teammates to help increase performance), and Social Support (e.g., helping a teammate through a difficult time). 
Table 3. Relative weights and confidence intervals for each dependent variable

\begin{tabular}{lccc}
\hline & & \multicolumn{2}{c}{$95 \%$ Confidence Interval $^{\mathrm{a}}$} \\
\cline { 3 - 4 } Dependent Variable & Relative Weight & Lower Bound & Upper Bound \\
\hline Training and Instruction & $.076^{\star}$ & .028 & .137 \\
Democratic Behaviour & .007 & -.016 & .021 \\
Social Support & $.030^{\star}$ & .003 & .068 \\
Positive Feedback & .002 & -.029 & .009 \\
\hline
\end{tabular}

Note. ${ }^{*}$ indicates the relative weight significantly different from zero at $p<.05$; af zero is not included, relative weight is significant

Using the Tukey procedure for planned comparison post-hoc analysis, we found that athlete leaders who self-rated themselves as being a formal leader also perceived themselves as engaging in significantly more Training and Instruction than informal athlete leaders $(p<.01 ; \mathrm{CI}=.04, .61)$ and followers $(p<.001$, $\mathrm{CI}=.29, .90)$. Similarly, informal athlete leaders perceived themselves to use more Training and Instruc- tion than followers $(p<.01, \mathrm{CI}=.02, .52)$. As for the athlete leadership behaviour of Social Support, it was found that self-rated formal athlete leaders $(p<.001$, $\mathrm{CI}=.14, .67)$ and informal athlete leaders $(p<.01, \mathrm{CI}$ $=.03, .47)$ perceived themselves displaying this leadership behaviour to a greater extent than followers. No other differences were found (see Figure 1).

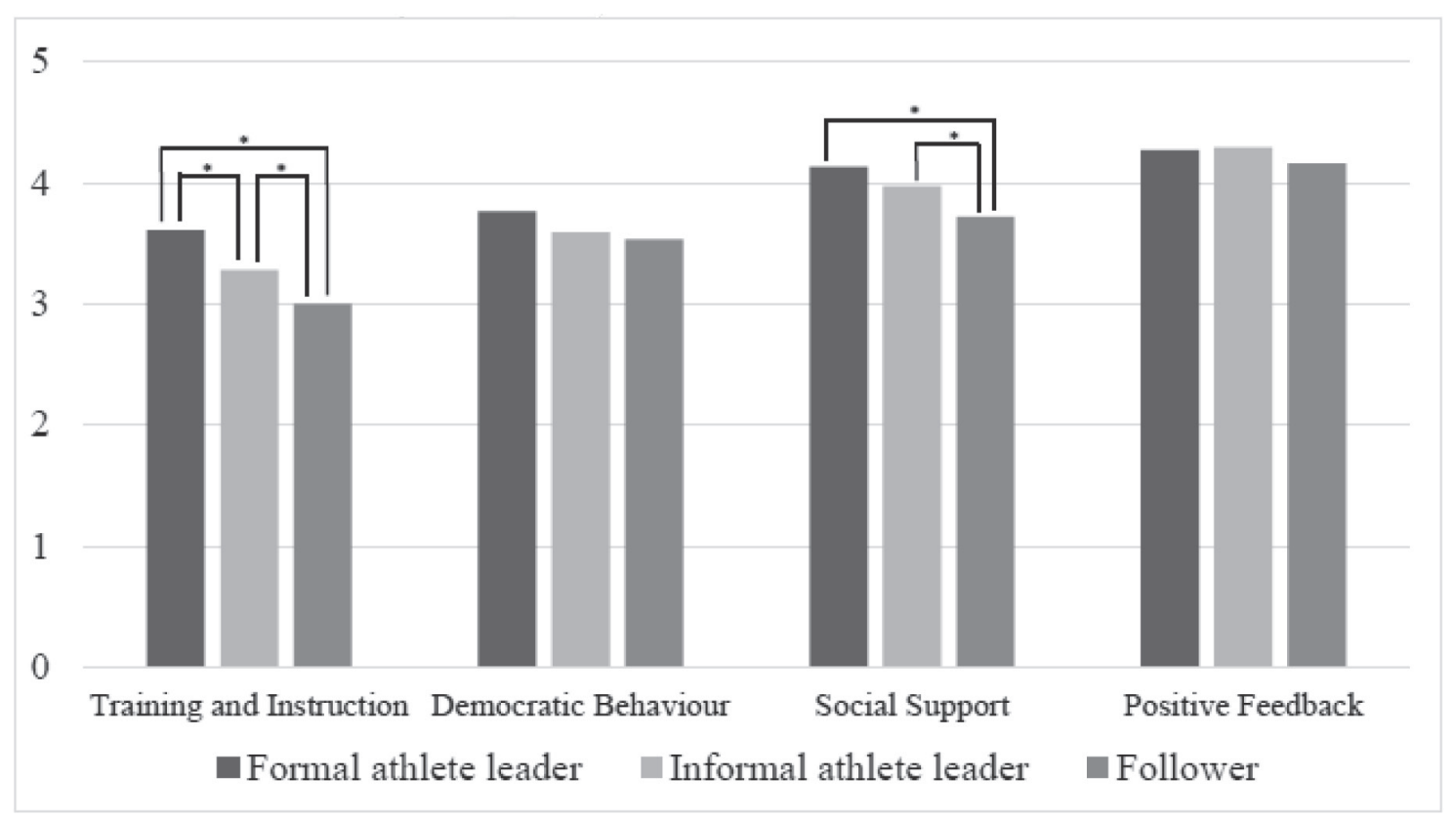

Figure 1. Frequency of self-rated leadership behaviours by athlete leader status

Note. ${ }^{*} p<.01$ 


\section{DISCUSSION}

In this research study, we examined whether an athlete's leadership status differentiated an individual's self-rated leadership behaviours in sport teams. A MANOVA, with relative weight analysis (Tonidandel \& LeBreton, 2013) and planned comparison post-hoc tests were conducted to examine differences in behaviour based on athlete self-rated leadership status (i.e., formal, informal, and non-leader). Results will be discussed in relation to Locke's (2003) integrated model of leadership.

First, results lend support to the top-down approach of leadership in Locke's (2003) model, as athlete leadership status differentiated two dimensions of athlete leader behaviours. In support of our hypotheses, it was found that formal athlete leaders reported using Training and Instruction leadership behaviours more frequently than informal athlete leaders and followers, with informal athlete leaders displaying it more than athlete followers. In regard to formal athlete leaders, this may not be surprising, as captains and assistant captains are often selected based upon their skill level or sport-specific experience (Loughead \& Hardy, 2005; Moran \& Weiss, 2006; Price \& Weiss, 2011), suggesting they would have the knowledge to provide task instruction. Further, research has found that majority of athletes who perform task-oriented functions (e.g., provide tactical decision-making) occupy a formal leadership role (Loughead et al., 2006). In relation to informal athlete leaders, results provide support for the task-oriented function in which emergent leaders may provide. While supporting previous work indicating that both formal and informal leaders provide task-oriented functions within teams (Fransen, Vanbeselaere, et al., 2014), the current study revealed that informal leaders do so to a lesser degree than formal leaders, but to a greater degree than followers.

Results also indicated that both formal and informal athlete leaders were found to provide more Social Support (i.e., concern for the welfare of others) compared to followers. While in contrast to our hypotheses, results do align with previous work which indicated that both designated leaders (i.e., formal) and emergent leaders (i.e., informal) provide social functions (e.g., promotes good relations among team members, deals with conflicts between teammates, is trusted by team members) within the team (Fransen, Vanbeselaere, et al., 2014; Loughead et al., 2006). Re- sults of the current study add to the extant literature by highlighting that formal and informal leaders reported using social support behaviours to a similar degree, yet to a greater degree than the athletes considered followers. This finding is novel when looking at the frequency of athlete leader behaviours.

While providing some evidence that leadership status can differentiate the behaviours of athlete leaders, the results also indicated that two of the athlete leader behaviours did not differ between statuses. As such, results also provide support for the shared leadership approach within Locke's (2003) model. Specifically, results indicated that both Democratic Behaviour and Positive Feedback were displayed equally among athletes. In essence, all athletes reported consulting with their teammates before making a decision that affected the group, while also rewarding teammates for good performances. Although this finding may seem somewhat intuitive, as both democratic decision-making and positive feedback would be desirable among athletes regardless of status, this was the first study to our knowledge to statistically examine whether differences would emerge in leadership behaviours among athletes. As no differences emerged for these two behaviours, results provide additional insight into the shared nature of leadership in sport.

Most intriguingly, an examination of the means indicated that regardless of whether the participants self-identified as an athlete leader (formal/informal) or athlete non-leader (follower), all three groups rated the frequency of their leadership behaviours relatively high (i.e., above the mid-point on a five-point scale, see Table 1). Although we found significant differences for two of the leadership behaviours, the overall finding suggests that leadership is distributed among the team, such that all team members perceive themselves as engaging in leadership behaviours, regardless of if they are a leader or follower. In addition to research that has suggested every team member at some point occupies a role of followership (Benson et al., 2016), the current study adds to that knowledge by revealing that every team member, including followers, at some point perceives themselves as engaging in behaviours typically considered leadership behaviours.

Taken together, the results support Locke's (2003) integrated model of leadership when applied to athlete leadership in sport. Specifically, Locke's model indicates a top-down approach, whereby individuals 
who have greater status (e.g., CEO or team captain) have the capacity to influence others who have lower status (e.g., employee or teammate). Further, the model also suggests that leadership can be distributed among individuals. That is, leadership can be "shared", and is a dynamic mutual process involving the emergence of both formal and informal leaders (Pearce, Manz, \& Sims, 2009). Within the framework of shared leadership, all team members have the potential to be a leader contingent on the situation and the capacities of the individuals within that situation. Team members provide leadership when their background and strengths are required and will relinquish leadership to others when they are needed (Manz, Pearce, Mott, Henson, \& Sims, 2013). Top-down or hierarchical leadership is still present with some individuals holding positions of responsibility (e.g., team captains) and making decisions when required, but the leadership process is fluid and can shift to other individuals (Locke, 2003; Manz et al., 2013). This aligns with research in organizational psychology, where group tasks were achieved through collective leadership (where a number of individuals emerged as leaders to guide a group through specific challenges; Friedrich et al., 2009). In sum, the findings from the present study indicate that both approaches to leadership (i.e., top-down, shared) are present within athlete leadership.

Given that all athletes engaged in leadership behaviours regardless of leadership status, the findings of this research have important implications for sport practitioners and researchers. More specifically, as athlete leadership behaviours have been positively related to perceptions of cohesion (Hardy, Eys, \& Loughead, 2008; Price \& Weiss, 2011, 2013; Vincer \& Loughead, 2010), satisfaction (Eys et al., 2007), enjoyment (Price \& Weiss, 2013), and collective efficacy (Price \& Weiss, 2013), it would follow that leadership behaviours be fostered in all athletes in order to influence individual and group outcomes. Therefore, coaches and sport psychology consultants should be aware of how athletes' behaviours can influence aspects of the team environment and should provide opportunities for all athletes to develop their leadership abilities. For example, all athletes could be provided the opportunity to attend leadership development workshops to enhance their leadership skills. By allowing all athletes to develop leadership behaviours, athletes may begin to feel as though their leadership contributions to the team are benefiting the entire group. The results of this study further supports this idea by indicating that followers also viewed themselves as displaying leadership behaviours to a similar degree as their leader counterparts. In fact, recent research has found that athletes, regardless of leadership status, who attended leadership workshops over the course of a season, engaged in leadership behaviours more frequently and had greater perceptions of task motivational climate and athlete satisfaction at the end of the season (Duguay, Loughead, \& Munroe-Chandler, 2016). Taken together, these findings suggest that followers may have the ability to influence the team environment, even if they do not regard themselves as a leader.

While the results of this research contribute to the athlete leadership literature, it is not without its limitations. The use of self-report measures may have resulted in response bias in terms of social desirability. In order to minimize this limitation, the questionnaires were distributed and returned to the investigator in unmarked envelopes and were completed independently by the athletes. Further, having self-rated measures for both predictor and criterion variables may have contributed to common method bias (Podsakoff, MacKenzie, Lee, \& Podsakoff, 2003). While having coach- or peer-assessed leadership status/behaviours will avoid this issue in future work, results still provide an interesting insight into athletes' self-perceptions concerning leadership behaviours. Specifically, regardless of an individuals' self-perceived leadership role (i.e., formal, informal, follower), all athletes' perceived themselves as displaying leadership behaviours.

Further, as it is obvious within a team who is a formal leader (either they are a captain or they are not), individuals may have self-rated as an informal leader, so as not to be viewed as a follower (which may be associated with negative connotations). In order to circumvent this bias, participants were asked to read the definitions of the two leadership roles and then instructed to indicate whether they perceived themselves as being either a formal or informal leader. Individuals were also instructed to continue to the next section if they did not perceive themselves as occupying either of the leadership roles (i.e., leave the leadership role section blank). In this sense, participants were unaware that they would be categorized as a "follower" in this study if they opted to not choose one of the two options, as the follower was not a choice presented to the participants. This choice was 
excluded in order to reduce the chance that participants would rate themselves as an informal leader to avoid being characterized as a "follower."

Another limitation relates to the low internal consistency value found for the athlete leadership behaviour of Autocratic Behaviour. Thus, we were unable to examine whether this leadership behaviour might differ based on athlete leadership status. This low value has been reported in previous coaching leadership research (Murray, 2006; Westre \& Weiss, 1991) and athlete leadership research (Paradis \& Loughead, 2012). The low alpha value found may be the result of utilizing an inventory (i.e., LSS) that was originally designed to examine coaching leadership behaviours (Chelladurai \& Saleh, 1980). Although responses to the athlete leader version of the LSS have supported its validity and reliability (Vincer \& Loughead, 2010), previous studies examined athletes' perceptions of their peers' leader behaviours, whereas we measured athletes' perceptions of their own leadership behaviours. Therefore, the items reflecting the dimension of Autocratic Behaviour may have been perceived as a negative behaviour and participants did not want to identify themselves as engaging in this type of behaviour. Conversely, the dimension of Autocratic Behaviour simply may not correctly reflect leadership behaviours displayed by athletes. Therefore, future research should examine whether the Autocratic Behaviour dimension of the LSS is relevant to athlete leaders.

Though the present study provides insight into leadership behaviours of athletes occupying different leadership roles, future directions can be suggested. This research was focused on examining the physical status attribute of leadership role (Jacob \& Carron, 1996). Given that other attributes have been deemed to be important indicators of status, such as experience (Jacob \& Carron, 1996), future research may wish to examine whether this variable distinguishes athlete leadership behaviours. For instance, Canadian intercollegiate sport is characterized by a five year eligibility rule for athletes. It would be interesting to determine which leadership behaviours are being used most frequently by athletes based on their eligibility at the intercollegiate level (1st year, 2nd year, 3rd year, and so on). This would help to determine which leadership behaviours should be targeted for intervention at different experience levels.

Although the purpose of the current study was to determine whether differences in leadership behaviour can be found based on leadership status, only four possible leadership behaviours were examined. As this study provides initial evidence that leadership occurs in both a hierarchical and lateral direction, future work may provide additional insight into this relationship by examining other athlete leader behaviours that have been identified (e.g., transformational leadership).

In summary, the results provided support for Locke's (2003) integrated model of leadership as applied to athlete leadership. In particular, athlete leadership occurs in the traditional top-down approach, whereby those with greater status sometimes engaged in more leadership behaviours than those with lower status. However, the results also suggested that leadership is distributed among team members, such that individuals who did not identify themselves as a leader (i.e., followers) were providing similar levels of leadership behaviours. However, the mean ratings of leadership behaviour from all athletes were above the mid-point, suggesting that all athletes engage in leadership-type behaviours regardless of leadership status. As formal and informal athlete leader behaviours have been the focus of previous athlete leadership research, results indicate that followers' behaviours should also be taken into consideration in future research.

\section{Acknowledgments}

This study was supported by an Ontario Graduate Scholarship and a Master's Social Sciences Humanities Research Council (SSHRC) Scholarship to the first author, and a SSHRC Insight Research Grant to the second and third authors. 


\section{REFERENCES}

1. Benson, A. J., Hardy, J., \& Eys, M. (2016). Contextualizing leaders' interpretations of proactive followership. Journal of Organizational Behaviour, 37, 949-966. doi:10.1002/job.2077

2. Bray, J. H., \& Maxwell, S. E. (1982). Analyzing and interpreting significant MANOVAs. Review of Educational Research, 52, 340-367.

3. Bucci, J., Bloom, G. A., Loughead, T. M., \& Caron, J. G. (2012). Ice hockey coaches' perceptions of athlete leadership. Journal of Applied Sport Psychology, 24, 243-259. doi:10.1080/10413200.2011.636416

4. Callow, N., Smith, M. J., Hardy, L., Arthur, C. A., \& Hardy, J. (2009). Measurement of transformational leadership and its relationship with team cohesion and performance level. Journal of Applied Sport Psychology, 21, 395-412. doi:10.1080/10413200903204754

5. Chelladurai, P., \& Saleh, S. (1980). Dimensions of leader behaviour in sports: Development of a leadership scale. Journal of Sport Psychology, 2, 34-45.

6. Crozier, A. J., Loughead, T. M., \& Munroe-Chandler, K. J. (2013). Examining the benefits of athlete leaders in sport. Journal of Sport Behaviour, 36, 346.

7. Dillon, W. R., \& Goldstein, M. (1984). Multivariate analysis: Methods and applications. New York, NY: Wiley.

8. Duguay, A. M., Loughead, T. M., \& Munroe-Chandler, K. J. (2013). Athlete leadership behaviours: Investigating their importance and the impact of team tenure. Paper presented at the Canadian Society for Psychomotor Learning and Sport Psychology Conference, Kelowna, British Columbia, Canada.

9. Duguay, A. M., Loughead, T. M., \& Munroe-Chandler, K. J. (2016). The development, implementation, and evaluation of an athlete leadership development program with female varsity athletes. The Sport Psychologist, 30, 154-166. doi:10.1123/ tsp.2015-0050

10. Dupuis, M., Bloom, G. A., \& Loughead, T. M. (2006). Team captains' perceptions of athlete leadership. Journal of Sport Behaviour, 29, 60-78.

11. Eys, M. A., Carron, A. V., Bray, S., \& Beauchamp, M. (2003). Role ambiguity and athlete satisfaction. Journal of Sports Sciences, 21, 391-401. doi:10.1080/0264041031000071137

12. Eys, M. A., Loughead, T. M., \& Hardy, J. (2007). Athlete leadership dispersion and satisfaction in interactive sport teams. Psychology of
Sport and Exercise, 8, 281-296. doi:10.1016/j. psychsport.2006.04.005

13. Fransen, K., Coffee, P., Vanbeselaere, N., Slater, M., De Cuyper, B., \& Boen, F. (2014). The impact of athlete leaders on team members' team outcome confidence: A test of mediation by team identification and collective efficacy. The Sport Psychologist, 28, 347-360. doi:10.1123/tsp.2013-0141

14. Fransen, K., Vanbeselaere, N., De Cuyper, B., Vande Broek, G., \& Boen, F. (2014). The myth of the team captain as principal leader: extending the athlete leadership classification within sport teams. Journal of Sports Sciences, 32, 1389-1397. doi:10.1080/02640414/2014.891291

15. Friedrich, T. L., Vessey, W. B., \& Schuelke, M. J. (2009). A framework for understanding collective leadership: The selective utilization of leader and team expertise within networks. The Leadership Quarterly, 20, 933-958.

16. Gould, D., \& Voelker, D. K. (2010). Youth sport leadership development: Leveraging the sports captaincy experience. Journal of Sport Psychology in Action, 1, 1-14. doi:10.1080/21520704.2010.49 7695

17. Greenlees, I., Webb, H., Hall, B., \& Manley, A. (2007). Curmudgeon or golden-ager?: Reported exercise participation influences the perception of older adults. Journal of Sport and Exercise Psychology, 29, 333-347.

18. Hardy, J., Eys, M. A., \& Loughead, T. M. (2008). Does communication mediate the athlete leadership to cohesion relationship? International Journal of Sport Psychology, 39, 329-345.

19. Hoption, C., Christie, A., \& Barling, J. (2012). Submitting to the follower label: Followership, positive affect, and extra role behaviours. ZeitschriftfürPsychologie, 220, 221-230. doi:10.1027/21512604/a000116

20. Huberty, C. J., \& Morris, J. D. (1989). Multivariate analysis versus multiple univariate analyses. Psychological Bulletin, 105, 302-308.

21. Jacob, C. S., \& Carron, A. V. (1996). Sources of status in sport teams. International Journal of Sport Psychology, 27, 369-382.

22. Jacob, C. S., \& Carron, A. V. (1998). The association between status and cohesion in sport teams. Journal of Sports Sciences, 16, 187-198. 
23. Jacob Johnson, C. S. (2004). Status in sport teams: Myth or reality? International Sports Journal, 8, 55-64. doi:

24. Jeffery-Tosoni, S. M., Eys, M. A., Schinke, R. J., \& Lewko, J. (2011). Youth sport status and perceptions of satisfaction and cohesion. Journal of Sport Behaviour, 34, 150-159.

25. Johnson, J. W. (2000). A heuristic method for estimating the relative weight of predictor variables in multiple regression. Multivariate Behavioural Research, 35, 1-19. doi:10/1207/S15327906MBR3501_1

26. Landers, D. M., Arent, S. M., \& Lutz, R. S. (2001). Affect and cognitive performance in high school wrestlers undergoing rapid weight loss. Journal of Sport and Exercise Psychology, 23, 307-316.

27. Locke, E. A. (2003). Leadership: Starting at the top. In C. L. Pearce \& J. A. Conger (Eds.), Shared leadership: Reframing the hows and whys of leadership (pp. 271-284). Thousand Oaks, CA: Sage.

28. Loughead, T. M. (2017). Athlete leadership: A review of the theoretical, measurement, and empirical literature. Current Opinion in Psychology. 16, 58-61. doi:10.16/j.copsyc.2017.04.014

29. Loughead, T. M., \& Hardy, J. (2005). An examination of coach and peer leader behaviours in sport. Psychology of Sport and Exercise, 6, 303312. doi:10.1016/j.psychsport.2004.02.001

30. Loughead, T. M., Hardy, J., \& Eys, M. A. (2006). The nature of athlete leadership. Journal of Sport Behaviour, 29, 142-158.

31. Manz, C. C., Pearce, C. L., Mott, J. W., Henson, Z., \& Sims, H. P. (2013). Don't take the lead...share the lead. Organizational Dynamics, 42, 54-60. doi:10.1016/j.orgdyn.2012.12.007

32. Martin, L. J., Balderson, D., Hawkins, M., Wilson, K., \& Bruner, M. W. (in press). Groupness and leadership perceptions in relation to social identity in youth sport. Journal of Applied Sport Psychology, advanced online publication. doi:10.1080/10 413200.2016.1238414

33. Moran, M. M., \& Weiss, M. R. (2006). Peer leadership in sport: Links with friendship, peer acceptance, psychological characteristics, and athletic ability. Journal of Applied Sport Psychology, 18, 97113. doi:10.1080/10413200600653501

34. Murray, N. P. (2006). The differential effect of team cohesion and leadership behaviour in high school sports. Individual Differences Research, 4, 216-225.
35. Olson, C. L. (1974). Comparative robustness of six tests in multivariate analysis of variance. Journal of the American Statistical Association, 69, 894-908.

36. Paradis, K. F., \& Loughead, T. M. (2012). Examining the mediating role of cohesion between athlete leadership and athlete satisfaction in youth sport. International Journal of Sport Psychology, 43, 117-136.

37. Pearce, C. L., \& Conger, J. A. (2003). Shared leadership: Reframing the hows and whys of leadership. Thousand Oaks, CA: Sage.

38. Pearce, C. L., Manz, C. C., \& Sims, H. P. (2009). Where do we go from here? Is shared leadership the key to team success? Organizational Dynamics, 38, 234-238. Doi:10.1016/j.orgdyn.2009.04.008

39. Pearce, C. L., \& Sims, H. P. (2002). Vertical versus shared leadership as predictors of the effectiveness of change management teams: An examination of aversive, directive, transactional, transformation$\mathrm{al}$, and empowering leader behaviours. Group Dynamics: Theory, Research, and Practice, 6, 172-197. doi:10.1037/1089-2699.6.2.172

40. Podsakoff, P. M., MacKenzie, S. B., Lee, J.-Y., \& Podsakoff, N. P. (2003). Common method biases in behavioural research: a critical review of the literature and recommended remedies. Journal of Applied Psychology, 88, 879-903.

doi:10.1037/0021-9010.88.5.879

41. Price, M. S., \& Weiss, M. R. (2011). Peer leadership in sport: Relationships among personal characteristics, leader behaviours, and team outcomes. Journal of Applied Sport Psychology, 23, 49-64. doi $: 10.1080 / 10413200.2010 .520300$

42. Price, M. S., \& Weiss, M. R. (2013). Relationships among coach leadership, peer leadership, and adolescent athletes' psychosocial and team outcomes: A test of transformational leadership theory. Journal of Applied Sport Psychology, 25, 265279. doi: $10.1080 / 10413200 / 2012.725703$

43. R Core Team (2013). R: A language and environment for statistical computing. R Foundation for Statistical Computing, Vienna, Austria. URL: http://www.R-project.org/.

44. Stevens, J. P. (1996). Applied multivariate statistics for the social sciences (3rd ed.). Mahwah, JN: Erlbaum.

45. Tonidandel, S., \& LeBreton, J. M. (2011). Relative importance analysis: A useful supplement to regression analysis. Journal of Business and Psychology, 26, 1-9. doi:10/1007/s10869-010-9204-3 
46. Tonidandel, S., \& LeBreton, J. M. (2013). Beyond step-down analysis: A new test for decomposing the importance of dependent variables in MANOVA. Journal of Applied Psychology, 98, 469-477. doi:10/1037/a0032001

47. Vanderslice, V. J. (1988). Separating leadership from leaders: An assessment of the effect of leader and follower roles in organizations. Human Relations, 41, 677-696.

48. Vincer, D., \& Loughead, T. M. (2010). The relationship among athlete leadership behaviours and cohesion in team sports. The Sport Psychologist, 24, 448-467.

49. Weiss, M. R., \& Smith, A. L. (2002). Friendship quality in youth sport: Relationship to age, gender, and motivation variables. Journal of Sport and Exercise Psychology, 24, 420-437.

50. Westre, K. R., \& Weiss, M. R. (1991). The relationship between perceived coaching behaviours and group cohesion in high school football teams. The Sport Psychologist, 5, 41-54.

\section{HIERARCHISCHES ODER GETEILTES LEADERSHIP? UNTERSUCHUNG DER UNTERSCHIEDE IN VERHALTENSWEISEN VON SPORT-LEADERN AUF GRUND DES LEADER-STATUS IM SPORT}

\section{Zusammenfassung}

Ziel dieser Untersuchung ist die Erkundung der Unterschiede in den Verhaltensweisen von Sportleadern auf Grund des eigenen eingeschätzten Leader-Status. Sportler verschiedener Colleges $(\mathrm{N}=299)$ haben selbstständig ihren Leader-Status identifiziert (formeller Leader, informeller Leader, Anhänger) und die Häufigkeit ihres eigenen Leaderverhaltens eingeschätzt. Die Ergebnisse haben gezeigt, dass formelle Sportleader häufiger in Training und Schulung engagiert sind als informelle Leader; bei informellen Sportleadern ist das Engagement in diesen Dimensionen größer als bei Anhängern. Bei formellen und informellen Sportleadern ist ein intensiveres Engagement in gesellschaftlicher Unterstützung ausgeprägt als bei Anhängern. Die Ergebnisse gewähren präliminäre Beweise für einen hierarchischen Ansatz des Leaderships bei Sportlern. Es wurden keine Unterschiede in demokratischem Verhalten weder in positivem Feedback festgestellt, was darauf hinweist, dass Sport-Leadership auch unter den Mitspielern distribuiert wird. Die Ergebnisse dieser Arbeit geben wichtige „praktische Implikationen“ für alle Sportarbeiter in Bezug auf die Entwicklung des Sportleaderships.

\section{Schlüsselwörter: GETEILTES LEADERSHIP / GRUPPENDYNAMIK / SPORTTEAMS / STATUS / SPORTLEADER}

Received: 27.06. 2017. Accepted: 27.10. 2017 


\title{
ХИЈЕРАРХИЈСКО ИЛИ ПОДЕЉЕНО ЛИДЕРСТВО? ИСПИТИВАЊЕ РАЗЛИКА У ПОНАШАЫИМА СПОРТСКИХ ЛИДЕРА НА ОСНОВУ ЛИДЕРСКОГ СТАТУСА У СПОРТУ
}

\author{
Алисон J Крозиер ${ }^{1}$, Тод М. Лоугхед², Криста Ј. Мунро-Шандлер ${ }^{2}$ \\ ${ }^{1}$ Универзитет Јужан Аустралија, Школа здравственних наука, Аделаиде, Аустралија \\ ${ }^{2}$ Универзитет Виндзор, Одјељење Хумане кинетике, Винздор, Онтарио, Канада
}

\begin{abstract}
Сажетак
Циљ овог истраживања је да се испитају разлике у понашањима спортских лидера на основу споственог процењеног лидерског статуса. Спортисти различитих колеџа ( $\mathrm{N}=299)$ су самостално идентификовали свој лидерски статус (тј.формални лидер, неформални лидер, следбеник) и оценили учесталост свог сопственог лидерског понашања. Резултати су показали да су се формални спортски лидери ангажовали чешће у Трениніу u Обуци него неформални спортски лидери; код неформалних спортских лидера је веће ангажовање у овим димензијама него код следбеника. Шта више, код формалних и неформалних спортских лидера је потврђено веће ангажовање у Друшйвеној йоgрици него код следбеника. Ови налази пружају прелиминарне доказе за хијерархијски приступ лидерству код спортиста. Нису пронађене разлике код Демокрайской йонашаға, као ни код Позийивне йоврайне информације, што указује на то да се спортско лидерство такође дистрибуира међу саиграчима. Резултати овог истраживања пружају важне “практичне импликације” за спортске раднике у погледу развоја спортског лидерства.
\end{abstract}

КљУчне речи: ПОДЕљЕНО ЛИДЕРСТВО, ДИНАМИКА ГРУПЕ, СПОРТСКИ ТИМОВИ, СТАТУС, СПОРТСКИ ЛИДЕР

\section{УВОД}

Постоји очигледна сагласност у спортској литератури о томе да је спортско лидерство значајно како за индивидуалне тако и за тимске резултате. Конкретно, понашање спортских лидера позитивно доприноси задовољству/уживању играча (Eys, Loughead, \& Hady, 2007; Price \& Weiss, 2013), поверењу (Fransen, Coffee, i sar., 2014; Price \& Weiss, 2013), кохезији тима (Callow, Smith, Hardy, Arthur, \& Hardy, 2009; Vincer \& Loughead, 2010), као и учинку (Callow i sar., 2009). С обзиром на ове позитивне предности, било би вредно испитати факторе који могу утицати на понашање које испољавају спортски лидери. Један такав фактор би могао бити лидерски статус спортисте у тиму, пошто су истраживачи утврдили вишеструке улоге спортских лидера које постоје у спорту (Crozier, Loughead, \& Munroe-Chandler, 2013; Fransen, Co- ffee, i sar., 2014; Loughead, Hardy, \& Eys, 2006). Haрочито, статус одражава количину значаја или престижа коју појединац поседује или му је дата на основу његовог положаја у односу на друге (Jacob\& Carron, 1998). Као такви, појединци се у оквиру групног окружења могу категорисати хијерархијски према њиховом статусу перципираном у поређењу са другима. Другим речима, они кој имају виши статус биће позиционирани на вишем степену хијерархијског статуса од оних са нижим статусом. У спорту, идентификована су четири главна извора статуса (Jacob Johnson, 2004) који обухватају физичке атрибуте појединца (нпр. учинак, искуство, улога лидера, играчка позиција), психолошке атрибуте (нпр. позитиван став, неговање тимског духа), демографске атрибуте (нпр. узраст, приходе) и односе са другима (нпр. родитељска подршка). Иако се може тврдити да су сва ова четири извора статуса значајна 
за спортске тимове, у овом истраживању смо се фокусирали на физичке атрибуте улоге спортисте у тиму, а посебно на улогу спортског лидера. У ствари, улога лидера је један од најважнијих извора статуса који су потврдили тимски спортисти (Jacob \& Carron, 1998).

У својој студији, Џејкоб и Карон (1998) су “користили” капитене или заменике капитена како би дефинисали улогу лидера. Овај референтни оквир је од посебног значаја, с обзиром на то да бити спортски лидер може значити више од простог приписивања лидерске улоге као што је именовање некога за капитена тима. Уместо тога, спортско лидерство је сложен, динамичан процес у којем више играча преузима лидерске улоге унутар тимова (Bucci, Bloom, Loughead, \& Caron, 2012; Crozier i sar., 2013; Fransen, Vanbeselaere, De Cuyper, Vande Broek, \& Boen, 2014). Идеја да бројни појединци могу заузети лидерске улоге је укорењена у оквиру приступа у којем се лидерство дели или дистрибуира (Pearce \& Conger, 2003). Концепт подељеног лидерства је у супротности са традиционалним приступом где постоји једна главна особа, док је други прате. Овај традиционални приступ одозго према доле био је доминантан у истраживању лидерства у спорту које је испитивало улогу тренера као лидера. Само су истраживања из протекле деценије посвећена разумевању подељеног лидерства у спорту, где су и тренери и спортисти могли обезбедити лидерску позицију у оквиру тима (Loughead \& Hardy, 2005).

У погледу спортског лидерства конкретно, улога спортисте лидера је дефинисана као спортиста који заузима формалну или неформалну улогу у оквиру тима и који има утицај на друге чланове тима како би се постигао заједнички циљ (Loughead i sar., 2006). Ова дефиниција истиче да се лидерске улоге могу делити или широко дистрибуирати међу члановима тима, као и да постоје две врсте улога спортских лидера. Формални лидери су они појединци који су одређени као лидери од стране организације или тима (нпр. капитени), док су неформални лидери они појединци који се појављују као лидери кроз искуство и интеракцију са другим члановима тима. Пошто је предложена ова дефиниција спортског лидера, трећа улога, која је призната од стране истраживача, је улога спортисте који није лидер (тј. следбеника) (Crozier i sar., 2013).
Ова студија је руковођена Локовим интегрисаним моделом лидерства (2003) који је развијен у организационој психологији, а који предлаже да подељено лидерство укључује и хијерархијски утицај на горе или на доле као и латерални (бочни) утицај. Када се примени на спортско лидерство, хијерархијски утицај указује на то да се капитени и заменици капитена (формалне врсте лидера) препознају као највиши извор статуса спортског лидерства, након којих следе неформални спортски лидери, а затим следбеници (тј. према хијерархијском утицају). Што се тиче латералног утицаја овог модела, чланови тима се посматрају као једнаки и међусобно зависни (без обзира на статус). Неколико претпоставки се везује за Локов модел. Прва је да се сви чланови тима не формирају једнако на основу њиховог статуса - формални лидери имају виши статус од неформалних лидера, а обе врсте спортских лидера имају виши статус у односу на следбенике. Друга претпоставка је да и латерални и хијерархијски утицај доприносе ефикасности екипе и не треба их сматрати међусобно искључивим (Pearce \& Sims, 2002).

Док Локов интегрисани модел лидерства (2003) није испитан, према нашим сазнањима, у односу на спортско лидерство, истраживања су указивала на то да у спорту постоји формална хијерархија, што обезбеђује структуру у погледу тога како појединци треба да изнесу своје улоге (Benson, Hardy, \& Eys, 2016). Даље, постоје извесни докази који истичу применљивост ових модела, јер одређене улоге спортских лидера (тј. формалне и неформалне) могу обезбедити различите и/или сличне врсте лидерског понашања у њиховим тимовима. У квалитативном истраживању предности у вези са присуством формалних и неформалних спортских лидера, Крозијер и сар. (2013) су показали да се лидерска понашања наводе као предност која је карактеристична за формалне лидере (нпр. капитене), али не и за неформалне лидере. Насупрот томе, резултати су даље идентификовали лидерска понашања подстицања саиграча и тражења залагања од саигра-

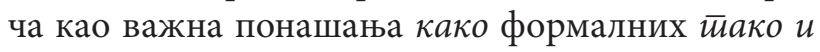
неформалних лидера. Док ови резултати указују на то да су формални и неформални лидери значајни јер обезбеђују различита, али и слична, лидерска понашања својој екипи, није било могуће

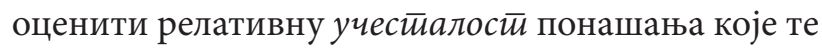
различите лидерске улоге испољавају. 
Шта више, уз неке изузетке (нпр. Benson, Hardy, \& Eys, 2016) до данас није било истраживања која су испитивала улогу следбеника у спорту. Из организационе психологије знамо да следбеници имају мање одговорности од лидера (Vanderslice, 1988) као и да се посматрају и осећају мање важним од оних који заузимају лидерске улоге (Hoption, Christie, \& Barling, 2012). Међутим, оно што горе наведени резултати нису успели да покажу је да ли се спортисти (лидери, следбеници) ангажују у сличним или различитим облицима лидерских понашања зависно од њихове лидерске улоге (статуса). Одређивање оних понашања за која спортисти сматрају да ће испољити у различитим лидерским улогама би пружило практична сазнања стручњацима који раде са спортистима (тј. тренерима, спортским психолозима). Конкретно, знати који спортисти (тј.улоге) испољавају одређена лидерска понашања значи омогућити практичарима да развију лидерске програме обуке посебно прилагођене читавој спортској екипи. Тренутно, већи број лидерских обука које се спортистима пружају намењен је формалним лидерима (Gould \& Voelker, 2010). Међутим, неформални лидери такође делују као примарни извор лидерства на многе спортисте (Fransen, Vanbeselaere, i sar., 2014), и стога би и њима требало пружити прилику да унапреде своје лидерске вештине.

У погледу лидерских понашања, од значаја за ову студију, иако су се разне мере користиле за оцењивање спортског лидерства, Скала лидерства у спорту (ЛСС; Chelladurai \& Saleh, 1980) је показала снажна психометријска својства у поређењу са осталим мерама модификованим за процењивање лидерских понашања спортиста (Loughead, 2017). Конкретно, Скала лидерства у спорту (СЛС) мери пет димензија лидерског понашања: Обуку и инструктажу (побољшање спортске перформансе), Позитивну повратну информацију (препознавање и награђивање доброг учинка), Социјалну подршку (показивање бриге за добробит чланова тима), Демократско понашање (омогућавање члановима тима да учествују у доношењу одлука) и Аутократско понашање (доношење одлука независно од чланова тима).

Стога, циљ ове студије је био да се испита да ли постоје разлике између лидерских понашања појединца у тимским спортовима у зависности од властитог лидерског статуса спортисте који се самостално процењује. Са једне стране, Ло- ков интегрисани модел лидерства (2003) указује на разлике у лидерским понашањима на основу статуса појединца (тј.хијерархијски приступ). Како су истраживања указала да се формални лидери наводе чешће од неформалних лидера у обављању функција оријентисаних на задатке (Fransen, Vanbeselaere, i sar., 2014; Loughead i sar., 2006), претпоставља се да hе се спортски лидери разликовати по учесталости у којој се пријављује њихова ангажованост у понашањима везаним

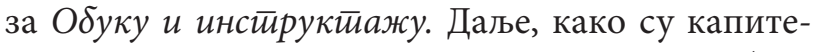
ни показали да користе аутократске технике (као део своје улоге, види Dupuis, Bloom, \& Loughead, 2006), претпоставља се да ће формални спортски лидери бити више укључени у Ауйокрайско йонашане у поређењу са неформалним пидерима. Са друге стране, овај модел такође указује на то да постоји могућност да лидерство буде подељено и да не би требало да буде разлика на основу статуса (тј. заједнички приступ). С обзиром на то да истраживања пријављују да су спортски лидери, без обзира на формални/неформални статус, корисни јер пружају подршку саиграчима, као и због тога јер траже залагање од својих саиграча (Crozier i sar., 2013), претпоставља се да се учесталост Соиијалне йоgрике, Позиииивне йоврайне информачије и Демокрайской йоначаньа неће разликовати на основу лидерског статуса спортисте, пошто су таква понашања у сличној мери дистрибуирана међу спортским лидерима. На крају, како постоје докази у организационој литератури да следбеници себе посматрају као оне који имају мање одговорности (Вандерслице, 1988) и тиме су мање важни од лидера (Hoption i sar., 2012) претпоставља се да ће се следбеници можда у мањој мери ангажовати у лидерским понашањима у односу на спортске лидере. Међутим, како постоје малобројна истраживања у спорту која се баве следбеницима, никакве а приори претпоставке нису дате унапред у вези са тим која ће се конкретно лидерска понашања разликовати код њих у односу на она која испољавају спортски лидери.

\section{МЕТОД РАДА}

\section{Испитаници}

Укупно 299 спортиста (90 мушкараца, 209 жена) из тимова са различитих колеџа и универзитета је учествовало у овом истраживању. Сви 
учесници су се такмичили или у оквиру Атлетског савеза универзитета Онтарио (OUA) или у оквиру Спортског савеза колеџа Онтариа (ОСАА) и били су чланови спортских тимова који су обухватали кошарку $(n=43)$, хокеј на леду $(n=122)$ и одбојку $(n=134)$. Просечна старост испитаника је износила 20.71 година $(S D=2.07)$. Учесници су били укључени у своје актуелне тимове у просеку од 2.17 година $(S D=1.19)$.

\section{Мерења}

\section{Лидерски статус спортисте}

Лидерски статус спортисте је био одређен тако што су учесници самостално идентификовали своју лидерску улогу коју заузимају у својим тренутним екипама. Учесницима је представљен опис формалног спортског лидера (тј. спортисте који је одабран од стране тима или тренера да буде на лидерској позицији, као што је капитен или заменик капитена), као и опис неформалног спортског лидера (тј.спортисте који није званично именован за вођу од стране тренера или тима, већ је свој статус успоставио кроз интеракцију са члановима тима). Од учесника се тражило да изаберу једну од ове две улоге спортских лидера која се може применити у њиховом случају. Ако учесник није одабрао ниједну од ове две опције, био је сврстан у категорију следбеника. Ова метода је коришћена у претходним истраживањима како би се извршила категоризација спортиста према лидерским улогама за које они сами сматрају да их заузимају у својим тимовима (Crozier i sar., 2013; Martin, Balderson, Hawkins, Wilson, \& Bruner, 2016). Мада признајемо дискретну природу ове категоризације, ова метода се сматрала прикладном за ову студију у циљу класификације спортиста према њиховим лидерским статусима које су самостално проценили. Сличне методе категоризације су коришћене у истраживањима која су испитивала почетни статус (тј. да ли је у питању спортиста који тек започиње такмичење на играчкој подлози и обично добија регуларно време за игру; Eys, Carron, Bray, \& Beauchamp, 2003) чиме је самостално процењен почетни статус представљао варијаблу од значаја (Jeffery-Tosoni, Eys, Schinke, \& Lewko, 2011). У овом истраживању, peзултати показују да је 67 (22.4\%) учесника идентификовало себе као формалне спортске лидере, 135 (45.1\%) као неформалне спортске лидере, а 98 (32.5\%) учесника се класификовало као спортиста који није лидер. Дистрибуција лидерства која је пронађена у овој студији употребом методе самосталног одабира лидерског статуса је слична оној која је откривена и у претходним истраживањима и студијама (Crozier i sar., 2013; Fransen, Coffee, i sar., 2014; Fransen, Vanbeselaere, i sar., 2014).

\section{Лидерска понашања спортиста}

Учесници су самостално оценили своја сопствена лидерска понашања помоћу Скале лидерства у спорту (SLS; Chelladurai \& Saleh, 1980). SLS се обично користи како би се измерила трансакциона тренерска понашања, али се такође ефикасно користи за процену лидерских понашања спортиста (Loughead \& Hardy, 2005; Vincer \& Loughead 2010). Поред тога, SLS је показала снажна психометријска својства у поређењу са другим мерама које су модификоване приликом процењивања понашања спортских лидера (Loughead, 2017). SLS је листа која се састоји од 40 тачака, којом се мери пет врста лидерског понашања. Димензија Обука и инструктажа се састоји од 13 тачака и процењује лидерско понашање које има за циљ побољшање спортске перформансе (нпр."Објашњавам члановима тима технике и тактике спорта."). Позитивна повратна информација се састоји од пет тачака и одражава склоност да се подстакне понашање помоћу препознавања и награђивања доброг учинка (нпр."Ценим и уважавам када члан тима оствари добар учинак."). Димензија Социјалне подршке се састоји од осам тачака и одражава меру у којој појединац показује бригу за добробит својих саиграча (нпр.”Помажем саиграчима када имају приватних проблема."). Димензија Демократско понашање се састоји од девет тачака и одражава меру у којој појединац омогућава саиграчима да учествују у доношењу одлука (нпр."Допуштам својим саиграчима да учествују у доношењу одлука."). Аутократско понашање обухвата пет тачака и представља склоност ка доношењу одлука независно од тима (нпр."Радим релативно независно у односу на друге чланове тима."). Све тачке су оцењиване на петостепеној Ликертовој скали на којој је 1 (никаgа) а 5 (увек). SLS је показала конвергентну (Paradis \& Loughead, 2012) и дискриминантну (Vincer \& Loughead, 2010) валидност, као и прихватљиве вредности унутрашње поузданости при оцени лидерских понашања спортиста (Loughead \& Hardy, 2005; Vincer \& Loughead, 2010). Дакле, ова листа мери 
своје циљане конструкте што је чини практичним средством за мерење лидерских понашања код спортиста. За ово истраживање, такође треба напоменути да је димензија спортског лидерства Аутократско понашање имала алфа коефицијент од 6.1 и изопштена је из даљих анализа.

\section{Поступак мерења}

Након прибављања етичког одобрења од стране универзитета, тренери су контактирани путем електронске поште и од њих је затражена дозвола да се испитају њихови спортисти. Пошто је сваки тренер дао дозволу, одређено је прикладно време за састанак са спортистима пре или после тренинга. На том састанку, спортистима је објашњен циљ овог истраживања. Поверљивост индивидуалних одговора је осигурана тако што је главни истраживач поделио упитнике (тј.демографске појединости, лидерски статус спортисте и SLS) у одвојеним неозначеним ковертама. Попуњени упитници су враћени назад у коверте како би се обезбедила додатна поверљивост. Враћање упитника означавало је пристанак за учествовање у истраживању, а попуњавање упитника је трајало отприлике 15 минута. Поред тога, свим учесницима је дата прилика да попуне гласачки листић како би стекли шансу да освоје поклон ваучер у вредности од $50 \$$ који су могли искористити у продавници спортске опреме, као подстицај да учествују у истраживању.

\section{Анализа података}

Како ठи се постигао циљ ове студије, спроведена је МАНОВА анализа да би се испитало да ли ће се формални спортски лидери, неформални спортски лидери и спортисти следбеници разликовати по учесталости у којој испољавају одређена лидерска понашања. Лидерски статус спортисте који су спортисти самостално процењивали је послужио као независна варијабла, док су четири преостале димензије Скале лидерства у спорту (SLS) послужиле као зависне варијабле. Како је дистрибуција између лидерских статуса била неуједначена, урађена је статистичка провера Pillai’s Trace, пошто се она сматра "најробуснијом" статистиком у случајевима када подаци наруше MAНОВА претпоставке (тј. једнаке јединице узорка; Olson, 1974).

Уколико је било значајно, да би се одредило која се специфична лидерска понашања спорти- ста разликују у односу на лидерски статус спортиста, спроведене cy post-hoc анализе. Post-hoc униваријантне АНОВА анализе се обично користе да се одреди где се разлике јављају у МАНОВА анализи (Huberty \& Morris, 1989; Tonidandel \& leBreton, 2013) и представљају доминантни поступак праћења у истраживању психологије спорта и вежбања (нпр. Greenlees, Webb, Hall, \& Manley, 2007; Landers, Arent, \& Lutz, 2001; Loughead\& Hardy, 2005; Weiss \& Smith, 2002). Међутим, постоји један велики недостатак у коришћењу узастопних униваријантних АНОВА анализа ради праћења значајне МАНОВА статистичке анализе. Употребом вишеструких АНОВА анализа, истраживачи занемарују корелације које се јављају између зависних варијабли (Bray \& Maxwell, 1982; Dillon \& Goldstein, 1984; Hubertyy \& Morris, 1989). Како би се зависне варијабле које су у корелацији узеле у обзир у МАНОВА дизајну, Тонидандел и ЛеБретон (2013) примењују технику анализе релатиивне иенжне (Johnson, 2000) на post-hoc процену значајних МАНОВА статистичких анализа. Анализа релативне тежине користи приступ трансформације варијабле који креира скуп нових варијабли који је максимално повезан са првобитним варијаблама, али су оне ортогоналне (не корелирају) међусобно. Према томе, анализа релативне тежине омогућава истраживачима да процене повезаност између независне варијабле (тј. лидерског статуса спортисте) и зависних варијабли (тј. лидерских понашања спортисте) док се међусобне корелације између зависних варијабли такође узимају у обзир. Дакле, анализа релативне тежине (Tonidandel \& LeBreton, 2011) je спроведена помоћу R статистичког пакета (R Core Team, 2013) да би се контролисале могуће међусобне корелације између четири врсте лидерских понашања спортиста. Релативне тежине повезане са сваком зависном варијаблом (тј. спортским лидерским понашањима) представљале су меру величине релативног ефекта (тј. проценат варијансе објашњене у свакој зависној варијабли помоћу независне варијабле; Tonidandel \& LeBreton, 2013). Даље, како би се оправдала FWER вероватноћа грешке код четири зависне варијабле, Бонферони усклађивање $(p=.05 / 4<.0125)$ је примењено на Тукијев post-hoc тест поређења са стриктним интервалима поузданости ( интервал поузданости [CI] од 99\%). 


\section{РЕЗУЛТАТИ}

\section{Дескриптивна статистика}

Табела 1 садржи средње вредности, стандардне девијације, као и алфа коефицијенте варијабли испитиваних у овом истраживању. Уопштено, средње вредности указују на то да су ови спор- тисти видели сеље како испољавају лидерска понашања у средњим до високим учесталостима (средње вредности су биле у распону од 3.00 до 4.29 , на петостепеној скали). Табела 2 садржи коефицијенте корелације између четири дате врсте лидерских понашања.

Табела 1. Средње вредности, стандардне девијације и алфа коефицијенти за димензију понашања лидера у односу на лидерски статус

\begin{tabular}{|c|c|c|c|c|}
\hline Варијабле & Формални & Неформални & „Следбеници“ & $\alpha$ \\
\hline 1. Тренинг и обука ${ }^{\mathrm{a}}$ & $\begin{array}{l}3.61 \\
(.65)\end{array}$ & $\begin{array}{l}3.28 \\
(.63)\end{array}$ & $\begin{array}{l}3.00 \\
(.67)\end{array}$ & .90 \\
\hline 2. Демократско понашање & $\begin{array}{l}3.76 \\
(.53)\end{array}$ & $\begin{array}{l}3.59 \\
(.57)\end{array}$ & $\begin{array}{l}3.53 \\
(.54)\end{array}$ & .70 \\
\hline 3. Социјална подршка ${ }^{a}$ & $\begin{array}{l}4.13 \\
(.51)\end{array}$ & $\begin{array}{l}3.97 \\
(.59)\end{array}$ & $\begin{array}{l}3.72 \\
(.59)\end{array}$ & .79 \\
\hline $\begin{array}{l}\text { 4. Позитивна повратна } \\
\text { информација }{ }^{\mathrm{a}}\end{array}$ & $\begin{array}{l}4.27 \\
(.57)\end{array}$ & $\begin{array}{l}4.29 \\
(.49)\end{array}$ & $\begin{array}{l}4.16 \\
(.53)\end{array}$ & .76 \\
\hline 5. Аутократско понашање $\mathrm{e}^{\mathrm{a}}$ & $\begin{array}{l}2.62 \\
(.67)\end{array}$ & $\begin{array}{l}2.62 \\
(.67)\end{array}$ & $\begin{array}{l}2.55 \\
(.66)\end{array}$ & $.61^{*}$ \\
\hline
\end{tabular}

Напомена: Резултати лидерског типа спортисте варирају од 1-5, са већим ठројевима који представљају већу фреквенцију ^Димензија је избрисана из даљих анализа због ниске вредности алфа; Стандардна одступања се налазе унутар заграда испод њихових одговарајућих средстава.

Табела 2. Биваријантне корелације димензија лидерског понашања

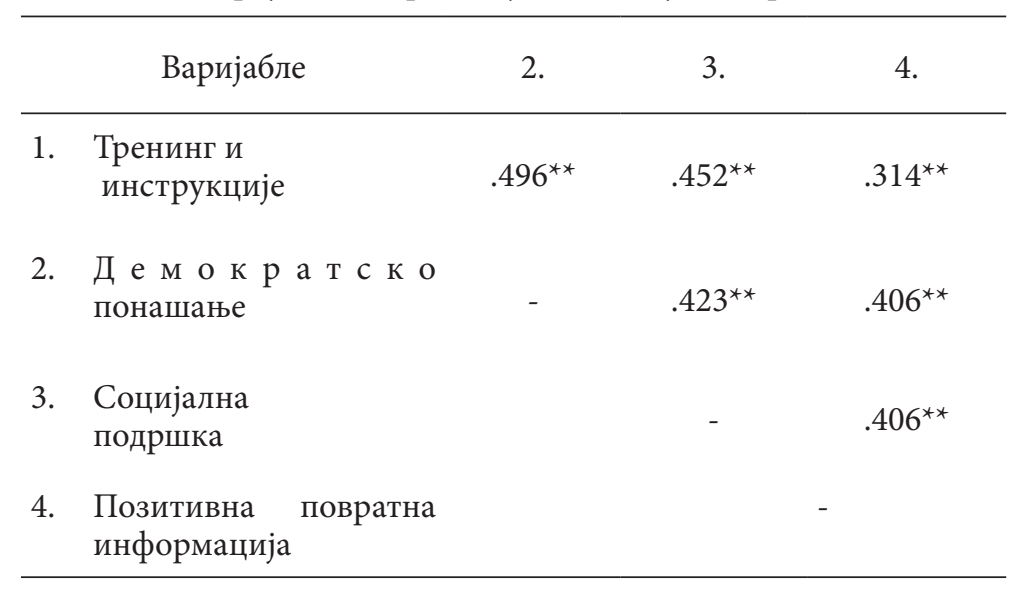

Напомена ${ }^{* *} p<.01$

\section{Главни резултати}

Целокупна МАНОВА је открила значајан ефекат мултиваријансе код лидерског статуса, Pillai's trace $=.138, F(8,588)=5.447, p<.001, \eta^{2}=.069$, указујући на то да је лидерски статус који су спор- тисти сами проценили значајно диференцирао самостално процењену учесталост лидерских понашања. Резултати анализе релативне тежине су представљени у Табели 3 и показују да је независна варијабла лидерског статуса спортиста 
била статистички различита код лидерских понашања спортиста Обука и инструктажа (нпр. давање упутстава саиграчима како би се повећала перформанса) и Социјална подршка (нпр.помоћ саиграчу који пролази кроз тежак период).

Табела 3. Релативна тежина и интервали поверења зависних варијабли

\begin{tabular}{lccc}
\hline & & \multicolumn{3}{c}{$95 \%$ Интервал поверења } & \\
\cline { 3 - 4 } Зависне варијабле & Релативна тежина & Доња граница & Горња граница \\
\hline 1. & $.076^{*}$ & .028 & .137 \\
2. & .007 & -.016 & .021 \\
3. & Семенинг и обука & .003 & .068 \\
4. & $.030^{*}$ & -.029 & .009 \\
\hline
\end{tabular}

Найомена * Означава значајност која се разликије од нуле за $p<.05 ;{ }^{\text {a } А к о ~ н у л а ~ н и ј е ~ у к љ у ч е н а, ~}$ релативна тежина је сигнификантна.

Помоћу Тукијевог поступка за планирано поређење post-hoc анализе, открили смо да спортски лидери који су себе оценили као формалне лидере такође себе виде знатно више укључене у Обуку и инструктажу него што је то случај са неформалним спортским лидерима $(p<.01 ; \mathrm{CI}=$ $.04, .61)$ и следбеницима $(p<.001, \mathrm{CI}=.29, .90)$. Слично томе, неформални спортски лидери су себе видели како више користе "тренинг и обуку" него следбеници $(p<.01, \mathrm{CI}=.02, .52)$. Што се тиче спортског лидерског понашања Социјална подршка, откривено је да спортисти који су себе проценили као формалне спортске лидере $(p<.001$, $\mathrm{CI}=.14, .67)$, као и неформални спортски лидери $(p<.01, \mathrm{CI}=.03, .47)$ себе виде како испољавају ову врсту лидерског понашања у већој мери него следбеници. Никакве друге разлике нису пронађене (види Слику 1).

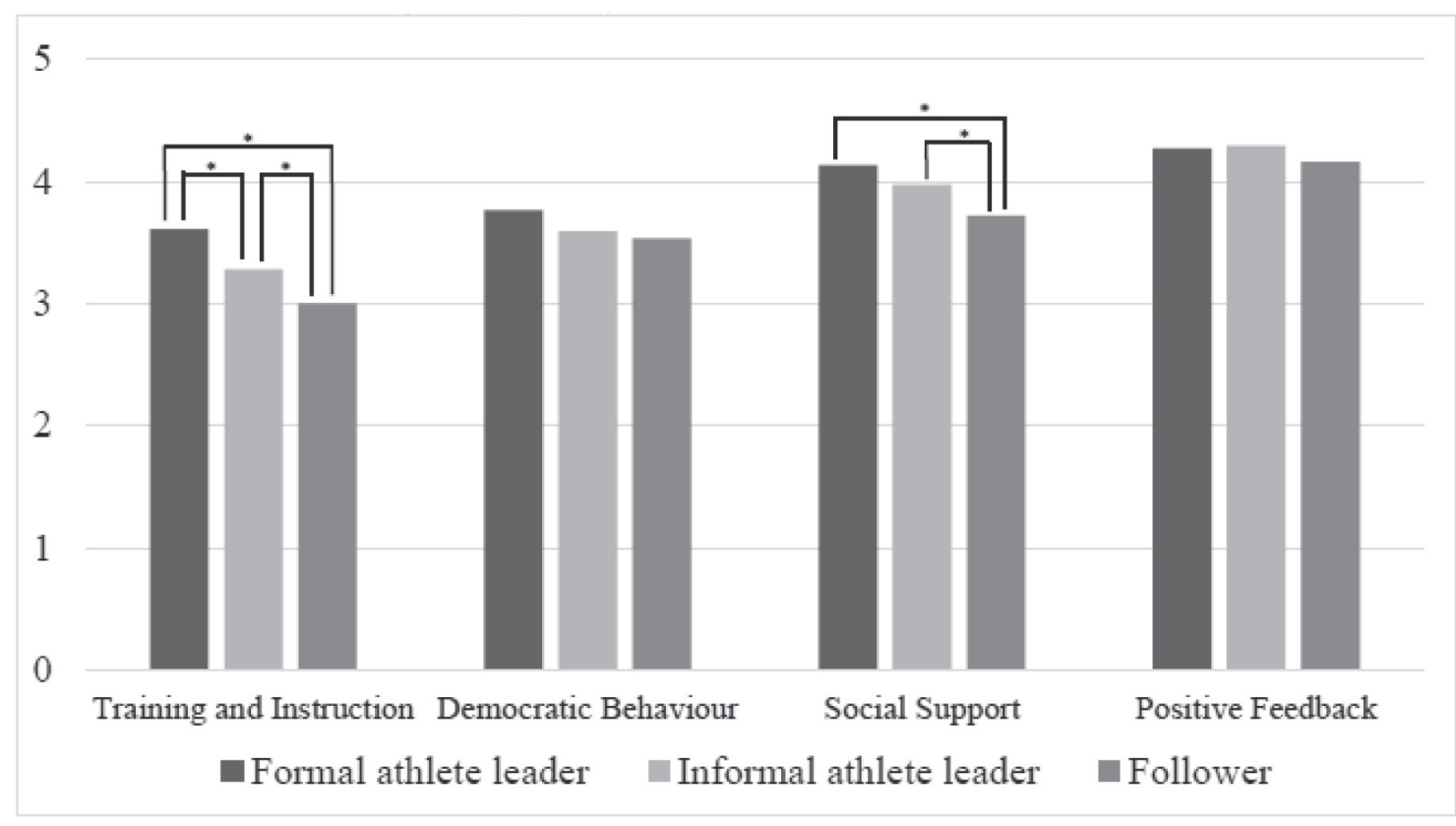

Слика 1. Учесталост самопроцењеног лидерског понашања према лидерском статусу спортиста Напомена: ${ }^{\star} p<.01$ 


\section{ДИСКУСИЈА}

У овој истраживачкој студији, испитивали смо да ли лидерски статус спортисте утиче на разлику у самопроцењеним лидерским понашањима појединца у оквиру спортских тимова. МАНОВА статистичка анализа варијансе, уз анализу релативне тежине (Tonidandel \& LeBreton, 2013), као и post-hoc тестови планираног упоређивања спроведени су како би се испитале разлике у понашању на основу самостално процењеног лидерског статуса спортиста (тј.формални лидер, неформални лидер и није лидер). Резултати ће бити разматрани у односу на Локов интегрисани модел лидерства (2003).

Прво, резултати пружају подршку хијерархијском приступу лидерству у оквиру Локовог модела (2003), пошто је лидерски статус направио разлику између две димензије лидерских понашања спортиста. У прилог нашој претпоставци, пронађено је да су формални спортски лидери “пријавили" много чешћу употребу Обуке и инструктаже као модел лидерског понашања него неформални спортски лидери и следбеници, док су неформални спортски лидери испољили ово лидерско понашање више него спортисти следбеници. У погледу формалних спортских лидера, ово можда и није изненађујуће, пошто се капитени и заменици капитена често бирају на основу степена њихових вештина или искустава специфичних за спорт (Loughead \& Hardyy, 2005; Moran $\&$ Weiss, 2006; Price \& Weiss, 2011), указујући на то да би они имали знања да пруже упутства везана за обављање задатака. Даље, истраживање је открило да већина спортиста који обављају задате функције (нпр.обезбеђују тактичко одлучивање) заузимају улогу формалних спортских лидера (Loughead i sar., 2006). У односу на неформалне спортске лидере, резултати пружају подршку у случају функција оријентисаних на обављање задатака које лидери у настајању могу пружити. Док пружа подршку претходном раду који указује на то да и формални и неформални лидери обезбеђују функције оријентисане на задатке у оквиру тимова (Fransen, Vanbeselaere, i sar., 2014), ова студија је открила да неформални лидери то чине у мањој мери него формални лидери, али у већој мери у односу на следбенике.

Резултати су такође указали да и формални и неформални лидери пружају више Социјалне по- дршке (тј.бриге за добробит других) у поређењу са следбеницима. Док су, супротно нашој претпоставци, резултати у складу са претходним истраживањима која су указала на то да и именовани лидери (тј.формални) и они у настајању (тј. неформални) обављају социјалне функције (нпр. промовишу добре односе међу члановима тима, баве се сукобима између саиграча, чланови тима имају поверења у њих) у оквиру тима (Fransen, Vanbeselaere, i sar., 2014; Loughead i sar., 2006). Peзултати овог истраживања доприносе постојећој литератури истичући да се формални и неформални лидери слично понашају у домену социјалне подршке, у већој мери од спортиста који себе сматрају следбеницима. Ово откриће је ново када се узме у обзир учесталост лидерских понашања спортиста.

Док пружају одређене доказе да лидерски статус може направити разлику између понашања спортских лидера, резултати су такође указали да се два од лидерских понашања спортиста нису разликовала према статусима. Као такви, резултати такође пружају подршку приступу подељеног лидерства у оквиру Локовог модела (2003). Конкретно, резултати указују на то да су се и Демократско понашање и Позитивна повратна информација испољавали подједнако међу спортистима. У суштини, сви спортисти су пријавили консултовање са својим саиграчима пре доношења неке одлуке која утиче на групу, а такође и награђивање саиграча који постигну добар учинак. Иако овај резултат може деловати донекле интуитивно, пошто би и демократско одлучивање и позитивна повратна информација били пожељни међу спортистима ठез обзира на статус, ово је било прво истраживање, према нашим сазнањима, које је статистички испитало да ли ће се разлике појавити у лидерским понашањима код спортиста. Како се никакве разлике нису појавиле код ова два понашања, резултати пружају додатни увид у заједничку природу лидерства у спорту.

Најзанимљивије, испитивање средњих вредности је указало на то да без обзира да ли су учесници идентификовали сеঠе као спортске лидере (формалне/неформалне) или спортисте који нису лидери (следбенике), све три групе су оцениле учесталост својих лидерских понашања релативно високо (тј.изнад средње вредности на скали од пет ступњева, види Табелу 1). Иако смо пронашли значајне разлике код два лидерска понашања, 
укупни резултат указује на то да се лидерство дистрибуира између чланова тима, пошто сви чланови тима себе виде као укључене у лидерска понашања, без обзира на то да ли су лидери или следбеници. Поред истраживања које је указало да сваки члан тима у неком тренутку заузима улогу следбеника (Benson i sar., 2016), ова студија доприноси том сазнању откривајући да сваки члан тима, укључујући и следбенике, у неком тренутку види себе укљученог у понашања која се обично сматрају лидерским понашањима.

Скупа посматрано, резултати подржавају Локов интегрисани модел лидерства (2003) када се примени на спортско лидерство. Конкретно, Локов модел указује на хијерархијски приступ при чему појединци који имају виши статус (нпр. који служе за пример другима или су капитени тима) имају потенцијал да утичу на друге који имају нижи статус (нпр.запослене или саиграче). Додатно, овај модел такође указује да се лидерство може дистрибуирати између појединаца. То јест, лидерство се може “поделити” и оно представља динамичан узајамни процес који укључује појаву како формалних тако и неформалних лидера (Pearce, Manz, \& Sims, 2009). У оквиру подељеног лидерства, сви чланови тима имају потенцијал да буду лидери у зависности од ситуације, као и од капацитета појединаца у оквиру те ситуациje. Чланови тима обезбеђују лидерску позицију када то захтевају њихова средина и способности, а одричу се лидерства и препуштају га другима када је то потребно (Manz, Pearce, Mott, Henson, \& Sims, 2013). Хијерархијско лидерство или лидерство одозго према доле је још увек присутно код неких појединаца који заузимају позиције које подразумевају одговорности (нпр. капитени тимова) и одлучивање када је потребно, али лидерски процес је флуидан и може се пребацити и на друге појединце (Locke, 2003; Manz i sar., 2013). Ово је у складу са истраживањем у организационој психологији где су задаци групе били остварени кроз колективно лидерство (где се известан број појединаца појављују као лидери како би водили групу кроз одређене изазове; Friedrich i sar.., 2009). Укратко, резултати ове студије указују на то да су оба приступа лидерству (тј. хијерархијско, подељено) присутна у оквиру лидерства у спорту.

Будући да се сви спортисти ангажују у лидерским понашањима без обзира на лидерски статус, резултати овог истраживања имају значајне импликације за спортске раднике и истраживаче. Конкретније, пошто су лидерска понашања спортиста позитивно повезана са доживљајем кохезије (Hardy, Eys, \& Loughead, 2008; Price \& Weiss, 2011, 2013; Vincer \& Loughead, 2010), задовољства (Еуs i sar.., 2007), уживања (Price \& Weiss, 2013), као и колективне ефикасности (Price \& Weiss, 2013), следи да ће лидерска понашања бити негована код свих спортиста како би се утицало на појединачне и групне резултате. Дакле, тренери, спортски психолози и педагози би требало да буду свесни како понашања спортиста могу утицати на аспекте тимског окружења и стога би требало да пруже прилику свим спортистима да развијају своје лидерске способности. На пример, свим спортистима би могла бити пружена прилика да присуствују радионицама за развијање лидерства како би унапредили своје лидерске вештине. Омогућавајући свим спортистима да развијају своја лидерска понашања, спортисти могу почети да осећају како њихови лидерски доприноси тиму представљају корист за читаву групу. Резултати ове студије додатно подржавају ову идеју указујући на то да су слеgбеници такође себе видели како испољавају лидерска понашања у сличној мери као и њихове колеге лидери. У ствари, недавно истраживање је открило да спортисти који су, без обзира на лидерски статус, похађали радионице о лидерству током једне сезоне, чешће учествовали у лидерским понашањима и боље доживљавали мотивациону климу за обављање задатака, као и да су показали веће задовољство у спорту на крају сезоне (Duguay, Loughead, \& Munroe-Chandler, 2016). Све у свему, ови резултати показују да следбеници такође могу имати способност да утичу на тимско окружење, чак иако не сматрају себе лидерима.

Иако резултати овог истраживања доприносе литератури о лидерству у спорту, то ипак није без ограничења. Употреба мера за самопроцену је могла довести до пристрасних одговора у смислу социјалне пожељности. Како би се ово ограничење свело на минимум, упитници су подељени и враћени истраживачу у неозначеним ковертама, а спортисти су их самостално попуњавали. Даље, употреба мера за самопроцену за предикторске и критеријумске варијабле је могла допринети уобичајеној пристрасности методе (Podsakoff, МаcKenzie, Lee, \& Podsakoff, 2003). Док ће употреба лидерских статуса/понашања процењиваних од стране тренера или колега помоћи да се овај 
проблем избегне у будућим радовима, резултати ипак пружају интересантан увид у самоойажаю $а$ спортиста у вези са лидерским понашањима. Конкретно, без обзира на самоопажену лидерску улогу појединца (тј.формални, неформални, следбеник), сви спортисти су себе доживели како испољавају лидерска понашања.

Шта више, пошто је очигледно ко је формални лидер у оквиру тима (без обзира да ли је капитен или не), појединци су могли себе проценити као неформалне лидере како не би били посматрани као следбеници (што се може довести у везу са негативним конотацијама). Како би се заобишла ова предрасуда, од учесника је захтевано да прочитају дефиниције две лидерске улоге, а затим су упућени да назначе да ли себе доживљавају било као формалне или неформалне лидере. Појединци су такође били упућени да пређу на следеће поглавље уколико себе нису доживели ни у једној од лидерских улога (тј. да оставе одељак о лидерској улози непопуњен). У том смислу, учесници нису били свесни да ће бити класификовани као “следбеници” у овом истраживању уколико су одлучили да не изаберу ниједну од ове две опције, пошто следбеник није био представљен учесницима као опција. Овакав избор није био укључен како би се смањила шанса да учесници оцене себе као неформалне лидере како би избегли да буду категорисани као “следбеници".

Друго ограничење се односи на ниску вредност унутрашње конзистентности која је пронађена код спортског лидерског понашања Аутократско понашање. Дакле, нисмо били у могућности да испитамо да ли се ово лидерско понашање можда разликује на основу лидерског статуса спортиста. Ова ниска вредност је била пријављена у претходним истраживањима тренерског лидерства (Murray, 2006; Westre \& Weiss, 1991), као и у истраживању лидерства код спортиста (Paradis \& Loughead, 2012). Пронађена ниска вредност алфа коефицијента може бити последица коришћења листе (тј.SLS) која је првобитно осмишљена да се испитају лидерска понашања тренера (Chelladurai \& Saleh, 1980). Иако су одговори на верзију SLS за испитивање лидерства код спортиста подржали њену валидност и поузданост (Vincer \& Loughead, 2010), претходне студије су испитивале како спортисти доживљавају лидерска понашања својих колега, док смо у овом истраживању мерили како спортисти доживљавају и виде своја сойсиивена лидерска понашања. Дакле, тачке које одражавају димензију Аутократског понашања су можда схваћене као негативно понашање и учесници нису желели да се идентификују као неко ко је укључен у ову врсту понашања. Насупрот томе, димензија Аутократског понашања можда просто није исправно одражавала лидерска понашања која спортисти испољавају. Стога, истраживања у будућности би требало да испитају да ли је димензија Аутократског понашања на SLS релевантна за спортске лидере. Иако ова студија пружа увид у лидерска понашања спортиста који заузимају различите лидерске улоге, могу се дати предлози за будућа истраживања. Ово истраживање је било фокусирано на испитивање физичког статуса атрибута лидерске улоге (Jacob \& Carron, 1996). С обзиром на то да се остали атрибути сматрају важним показатељима статуса, попут искуства (Jacob \& Carron, 1996), истраживања у будућности ће можда желети да испитају да ли ова варијабла прави разлику међу различитим лидерским понашањима. На пример, канадски спорт на нивоу колеџа се карактерише правилом петогодишње квалификације код спортиста. Било би интересантно да се одреди која лидерска понашања спортисти најчешће користе на основу њихове подобности на нивоу међу колеџима (прва година, друга година, трећа година, итд). Ово би помогло да се одреди која лидерска понашања треба узети за циљ при инетервенцији на различитим нивоима искуства.

Мада је циљ ове студије био да се испита да ли се разлике у лидерском понашању могу пронаћи на основу лидерског статуса, само четири могућа лидерска понашања су испитивана. Како ово истраживање пружа почетни доказ да се лидерство јавља и у хијерархијском и у латералном правцу, будући радови би могли пружити додатни увид у ову повезаност испитивањем других лидерских понашања спортиста која су идентификована (нпр. трансформационо лидерство).

Укратко, резултати су пружили подршку Локовом интегрисаном моделу лидерства (2003) како се примењује на спортско лидерство. Нарочито, спортско лидерство се јавља у традиционалном приступу одозго према доле, где се они са вишим статусом понекад ангажују више у лидерским понашањима од оних са нижим статусом. Међутим, резултати су такође указали на то да се лидерство дистрибуира међу члановима тима, пошто су они 
појединци који нису себе идентификовали као лидере (тј. следбеници) показали сличне нивое лидерских понашања. Међутим, средње оцене лидерског понашања од стране свих спортиста су биле изнад средње оцене, указујући на то да се сви спортисти укључују у неку врсту лидерског понашања, без обзира на њихов лидерски статус. Како су лидерска понашања формалних и неформалних спортских лидера била у фокусу претходних истраживања лидерства у спорту, резултати указују на то да би понашања следбеника такође требало узети у разматрање у будућим истраживањима.

\section{ЛИТЕРАТУРА}

1. Benson, A. J., Hardy, J., \& Eys, M. (2016). Contextualizing leaders' interpretations of proactive followership. Journal of Organizational Behaviour, 37, 949-966. doi:10.1002/job.2077

2. Bray, J. H., \& Maxwell, S. E. (1982). Analyzing and interpreting significant MANOVAs. Review of Educational Research, 52, 340-367.

3. Bucci, J., Bloom, G. A., Loughead, T. M., \& Caron, J. G. (2012). Ice hockey coaches' perceptions of athlete leadership. Journal of Applied Sport Psychology, 24, 243-259. doi:10.1080/10413200.2011.636416

4. Callow, N., Smith, M. J., Hardy, L., Arthur, C. A., \& Hardy, J. (2009). Measurement of transformational leadership and its relationship with team cohesion and performance level. Journal of Applied Sport Psychology, 21, 395-412. doi:10.1080/10413200903204754

5. Chelladurai, P., \& Saleh, S. (1980). Dimensions of leader behaviour in sports: Development of a leadership scale. Journal of Sport Psychology, 2, 34-45.

6. Crozier, A. J., Loughead, T. M., \& Munroe-Chandler, K. J. (2013). Examining the benefits of athlete leaders in sport. Journal of Sport Behaviour, 36, 346.

7. Dillon, W. R., \& Goldstein, M. (1984). Multivariate analysis: Methods and applications. New York, NY: Wiley.

8. Duguay, A. M., Loughead, T. M., \& Munroe-Chandler, K. J. (2013). Athlete leadership behaviours: Investigating their importance and the impact of team tenure. Paper presented at the Canadian Society for Psychomotor Learning and Sport Psychology Conference, Kelowna, British Columbia, Canada.

\section{Захвалност и признања}

Ово истраживање подржао је Истраживачки савет друштвених наука Онтарија (SSHRC) Стипендијом за дипломце Онтарија и Стипендијом за магистре друштвених наука првом аутору, као и грантом за спровођење свеобухватног истраживања који су доделили другом и трећем аутору.

9. Duguay, A. M., Loughead, T. M., \& Munroe-Chandler, K. J. (2016). The development, implementation, and evaluation of an athlete leadership development program with female varsity athletes. The Sport Psychologist, 30, 154-166. doi:10.1123/ tsp.2015-0050

10. Dupuis, M., Bloom, G. A., \& Loughead, T. M. (2006). Team captains' perceptions of athlete leadership. Journal of Sport Behaviour, 29, 60-78.

11. Eys, M. A., Carron, A. V., Bray, S., \& Beauchamp, M. (2003). Role ambiguity and athlete satisfaction. Journal of Sports Sciences, 21, 391-401. doi:10.1080/0264041031000071137

12. Eys, M. A., Loughead, T. M., \& Hardy, J. (2007). Athlete leadership dispersion and satisfaction in interactive sport teams. Psychology of Sport and Exercise, 8, 281-296. doi:10.1016/j. psychsport.2006.04.005

13. Fransen, K., Coffee, P., Vanbeselaere, N., Slater, M., De Cuyper, B., \& Boen, F. (2014). The impact of athlete leaders on team members' team outcome confidence: A test of mediation by team identification and collective efficacy. The Sport Psychologist, 28, 347-360. doi:10.1123/tsp.2013-0141

14. Fransen, K., Vanbeselaere, N., De Cuyper, B., Vande Broek, G., \& Boen, F. (2014). The myth of the team captain as principal leader: extending the athlete leadership classification within sport teams. Journal of Sports Sciences, 32, 1389-1397. doi:10.1080/02640414/2014.891291

15. Friedrich, T. L., Vessey, W. B., \& Schuelke, M. J. (2009). A framework for understanding collective leadership: The selective utilization of leader and 
team expertise within networks. The Leadership Quarterly, 20, 933-958.

16. Gould, D., \& Voelker, D. K. (2010). Youth sport leadership development: Leveraging the sports captaincy experience. Journal of Sport Psychology in Action, 1, 1-14. doi:10.1080/21520704.2010.49 7695

17. Greenlees, I., Webb, H., Hall, B., \& Manley, A. (2007). Curmudgeon or golden-ager?: Reported exercise participation influences the perception of older adults. Journal of Sport and Exercise Psychology, 29, 333-347.

18. Hardy, J., Eys, M. A., \& Loughead, T. M. (2008). Does communication mediate the athlete leadership to cohesion relationship? International Journal of Sport Psychology, 39, 329-345.

19. Hoption, C., Christie, A., \& Barling, J. (2012). Submitting to the follower label: Followership, positive affect, and extra role behaviours. ZeitschriftfürPsychologie, 220, 221-230. doi:10.1027/21512604/a000116

20. Huberty, C. J., \& Morris, J. D. (1989). Multivariate analysis versus multiple univariate analyses. Psychological Bulletin, 105, 302-308.

21. Jacob, C. S., \& Carron, A. V. (1996). Sources of status in sport teams. International Journal of Sport Psychology, 27, 369-382.

22. Jacob, C. S., \& Carron, A. V. (1998). The association between status and cohesion in sport teams. Journal of Sports Sciences, 16, 187-198.

23. Jacob Johnson, C. S. (2004). Status in sport teams: Myth or reality? International Sports Journal, 8, 55-64. doi:

24. Jeffery-Tosoni, S. M., Eys, M. A., Schinke, R. J., \& Lewko, J. (2011). Youth sport status and perceptions of satisfaction and cohesion. Journal of Sport Behaviour, 34, 150-159.

25. Johnson, J. W. (2000). A heuristic method for estimating the relative weight of predictor variables in multiple regression. Multivariate Behavioural Research, 35, 1-19. doi:10/1207/S15327906MBR3501_1

26. Landers, D. M., Arent, S. M., \& Lutz, R. S. (2001). Affect and cognitive performance in high school wrestlers undergoing rapid weight loss. Journal of Sport and Exercise Psychology, 23, 307-316.

27. Locke, E. A. (2003). Leadership: Starting at the top. In C. L. Pearce \& J. A. Conger (Eds.), Shared leadership: Reframing the hows and whys of leadership (pp. 271-284). Thousand Oaks, CA: Sage.
28. Loughead, T. M. (2017). Athlete leadership: A review of the theoretical, measurement, and empirical literature. Current Opinion in Psychology. 16, 58-61. doi:10.16/j.copsyc.2017.04.014

29. Loughead, T. M., \& Hardy, J. (2005). An examination of coach and peer leader behaviours in sport. Psychology of Sport and Exercise, 6, 303312. doi:10.1016/j.psychsport.2004.02.001

30. Loughead, T. M., Hardy, J., \& Eys, M. A. (2006). The nature of athlete leadership. Journal of Sport Behaviour, 29, 142-158.

31. Manz, C. C., Pearce, C. L., Mott, J. W., Henson, Z., \& Sims, H. P. (2013). Don't take the lead...share the lead. Organizational Dynamics, 42, 54-60. doi:10.1016/j.orgdyn.2012.12.007

32. Martin, L. J., Balderson, D., Hawkins, M., Wilson, K., \& Bruner, M. W. (in press). Groupness and leadership perceptions in relation to social identity in youth sport. Journal of Applied Sport Psychology, advanced online publication. doi:10.1080/10 413200.2016.1238414

33. Moran, M. M., \& Weiss, M. R. (2006). Peer leadership in sport: Links with friendship, peer acceptance, psychological characteristics, and athletic ability. Journal of Applied Sport Psychology, 18, 97113. doi:10.1080/10413200600653501

34. Murray, N. P. (2006). The differential effect of team cohesion and leadership behaviour in high school sports. Individual Differences Research, 4, 216-225.

35. Olson, C. L. (1974). Comparative robustness of six tests in multivariate analysis of variance. Journal of the American Statistical Association, 69, 894-908.

36. Paradis, K. F., \& Loughead, T. M. (2012). Examining the mediating role of cohesion between athlete leadership and athlete satisfaction in youth sport. International Journal of Sport Psychology, 43, 117-136.

37. Pearce, C. L., \& Conger, J. A. (2003). Shared leadership: Reframing the hows and whys of leadership. Thousand Oaks, CA: Sage.

38. Pearce, C. L., Manz, C. C., \& Sims, H. P. (2009). Where do we go from here? Is shared leadership the key to team success? Organizational Dynamics, 38, 234-238. Doi:10.1016/j.orgdyn.2009.04.008

39. Pearce, C. L., \& Sims, H. P. (2002). Vertical versus shared leadership as predictors of the effectiveness of change management teams: An examination of aversive, directive, transactional, transformational, and empowering leader behaviours. Group 
Dynamics: Theory, Research, and Practice, 6, 172197. doi:10.1037/1089-2699.6.2.172

40. Podsakoff, P. M., MacKenzie, S. B., Lee, J.-Y., \& Podsakoff, N. P. (2003). Common method biases in behavioural research: a critical review of the literature and recommended remedies. Journal of Applied Psychology, 88, 879-903.

doi:10.1037/0021-9010.88.5.879

41. Price, M. S., \& Weiss, M. R. (2011). Peer leadership in sport: Relationships among personal characteristics, leader behaviours, and team outcomes. Journal of Applied Sport Psychology, 23, 49-64. doi :10.1080/10413200.2010.520300

42. Price, M. S., \& Weiss, M. R. (2013). Relationships among coach leadership, peer leadership, and adolescent athletes' psychosocial and team outcomes: A test of transformational leadership theory. Journal of Applied Sport Psychology, 25, 265279. doi:10.1080/10413200/2012.725703

43. R Core Team (2013). R: A language and environment for statistical computing. R Foundation for Statistical Computing, Vienna, Austria. URL: http://www.R-project.org/.

44. Stevens, J. P. (1996). Applied multivariate statistics for the social sciences (3rd ed.). Mahwah, JN: Erlbaum.
45. Tonidandel, S., \& LeBreton, J. M. (2011). Relative importance analysis: A useful supplement to regression analysis. Journal of Business and Psychology, 26, 1-9. doi:10/1007/s10869-010-9204-3

46. Tonidandel, S., \& LeBreton, J. M. (2013). Beyond step-down analysis: A new test for decomposing the importance of dependent variables in MANOVA. Journal of Applied Psychology, 98, 469-477. doi:10/1037/a0032001

47. Vanderslice, V. J. (1988). Separating leadership from leaders: An assessment of the effect of leader and follower roles in organizations. Human Relations, 41, 677-696.

48. Vincer, D., \& Loughead, T. M. (2010). The relationship among athlete leadership behaviours and cohesion in team sports. The Sport Psychologist, 24, 448-467.

49. Weiss, M. R., \& Smith, A. L. (2002). Friendship quality in youth sport: Relationship to age, gender, and motivation variables. Journal of Sport and Exercise Psychology, 24, 420-437.

50. Westre, K. R., \& Weiss, M. R. (1991). The relationship between perceived coaching behaviours and group cohesion in high school football teams. The Sport Psychologist, 5, 41-54.

\title{
HIERARCHISCHES ODER GETEILTES LEADERSHIP? UNTERSUCHUNG DER UNTERSCHIEDE IN VERHALTENSWEISEN VON SPORT-LEADERN AUF GRUND DES LEADER-STATUS IM SPORT
}

\begin{abstract}
Zusammenfassung
Ziel dieser Untersuchung ist die Erkundung der Unterschiede in den Verhaltensweisen von Sportleadern auf Grund des eigenen eingeschätzten Leader-Status. Sportler verschiedener Colleges $(\mathrm{N}=299)$ haben selbstständig ihren Leader-Status identifiziert (formeller Leader, informeller Leader, Anhänger) und die Häufigkeit ihres eigenen Leaderverhaltens eingeschätzt. Die Ergebnisse haben gezeigt, dass formelle Sportleader häufiger in Training und Schulung engagiert sind als informelle Leader; bei informellen Sportleadern ist das Engagement in diesen Dimensionen größer als bei Anhängern. Bei formellen und informellen Sportleadern ist ein intensiveres Engagement in gesellschaftlicher Unterstützung ausgeprägt als bei Anhängern. Die Ergebnisse gewähren präliminäre Beweise für einen hierarchischen Ansatz des Leaderships bei Sportlern. Es wurden keine Unterschiede in demokratischem Verhalten weder in positivem Feedback festgestellt, was darauf hinweist, dass Sport-Leadership auch unter den Mitspielern distribuiert wird. Die Ergebnisse dieser Arbeit geben wichtige „praktische Implikationen“ für alle Sportarbeiter in Bezug auf die Entwicklung des Sportleaderships.
\end{abstract}

Schlüsselwörter: GETEILTES LEADERSHIP / GRUPPENDYNAMIK / SPORTTEAMS / STATUS / SPORTLEADER

Примљен: 27. 06. 2017.

Прихваћен: 27. 10. 2017. 